\section{NOVA TELLVS}

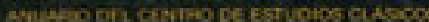

Nova Tellus

ISSN: 0185-3058

novatelu@servidor.unam.mx

Centro de Estudios Clásicos

México

Ramírez Batalla, Miguel Ángel

Tradición y costumbres en la religión romana

Nova Tellus, vol. 27, núm. 1, 2009, pp. 247-294

Centro de Estudios Clásicos

Distrito Federal, México

Disponible en: http://www.redalyc.org/articulo.oa?id=59115499009

- Cómo citar el artículo

- Número completo

- Más información del artículo

- Página de la revista en redalyc.org

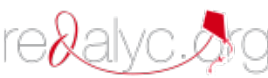

Sistema de Información Científica

Red de Revistas Científicas de América Latina, el Caribe, España y Portugal

Proyecto académico sin fines de lucro, desarrollado bajo la iniciativa de acceso abierto 


\title{
Tradición y costumbres en la religión romana
}

\author{
Miguel Ángel RamíRez Batalla \\ Universidad Nacional Autónoma de México \\ urbs753@latinmail.com
}

RESUMEN: El objetivo de este trabajo es mostrar el papel central de la tradición como criterio esencial de aceptación en la religión oficial romana. Se pretende destacar la relevancia de la esfera religiosa en Roma que afectaba a todas las clases sociales y provocaba distintas reacciones. Además, subraya algunos argumentos filosóficos que apoyaban o rechazaban la creencia en los dioses. Sin embargo, la validez de la religión romana se basaba en la tradición y los aristócratas romanos vieron la fidelidad a las antiguas costumbres religiosas como la principal característica de su historia.

$$
* * *
$$

ABSTRACT: The objective of this writing is to show the central role of tradition like essential criterion of acceptation in the Roman official religion. It pretends emphasize the importance of the religious sphere at Rome which affected all social classes and produced distinct reactions. In addition, it underlines some philosophical arguments that supported or rejected the belief in gods. Nevertheless the validity of the Roman religion was founded in tradition and the Roman aristocrats saw the loyalty to the ancient religious costumes like the principal characteristic of its history.

PALABRAS CLAVE: costumbre, filosofía, religión, Roma, sociedad, tradición.

KEYWORDS: habit, philosophy, religion, Rome, society, tradition.

RECEPCIÓN: 14 de julio de 2008.

ACEPTACIÓN: 21 de noviembre de 2008. 


\title{
Tradición y costumbres en la religión romana
}

\author{
Miguel Ángel Ramírez BATALLA
}

\begin{abstract}
Al acercarse a la historia romana inmediatamente se ve la importancia de la religión y de los fenómenos relacionados con la esfera sobrenatural. La necesidad de llevar una adecuada relación con las fuerzas espirituales y hacerlas favorables a Roma fue algo que los romanos buscaron constantemente mediante diversas formas. La religión fue un elemento que estuvo presente en la sociedad romana desde sus inicios, convirtiéndose en parte integrante de su vida cotidiana. Las instituciones religiosas formaban parte de las costumbres ancestrales que eran el referente moral y de conducta que sustentaba al Estado romano, por lo que quienes estaban a su cabeza eran sus más celosos guardianes. Aunque había varias formas de acercarse a lo divino, la religión tradicional tuvo un papel determinante para sustentar la creencia en los dioses y la continuidad de los cultos. Este trabajo pretende mostrar algunas maneras en que la tradición era el criterio primordial de aceptación para el culto religioso, de qué modo la historia romana estaba estrechamente enlazada con la religión y resaltar cómo los defensores del culto tradicional veían el talante romano frente a las costumbres religiosas a través del tiempo y la conclusión que extraían de este análisis.
\end{abstract}

\section{I}

La religión romana se basaba en prácticas como sacrificios y rituales tendientes a establecer el vínculo entre dioses y hom-

NOVA TELLVS, 27•1, 2009 
bres para que éstos consiguieran el favor de aquéllos. No era una religión revelada que tuviera dogmas definidos ni una institución a la cual afiliarse; los rituales eran el centro de la práctica, no la creencia, lo importante era la participación de todos, lo cual ayudaba a fortalecer el carácter comunitario y cohesivo de la religión en la sociedad. En Roma, el aparato religioso estatal fue representado por magistrados religiosos como los diversos sacerdotes reunidos en colegios que tenían como cabeza al pontífice máximo, quien junto con los flamines, los pontífices y las vestales formaban la estructura religiosa. Otros actores eran los augures que cuidaban las formalidades religiosas en las asambleas para asegurar que los procedimientos fueran adecuados y que las señales sobrenaturales indicaran la aprobación divina. Por su parte, los arúspices interpretaban los hígados de los animales sacrificados para ver si eran favorables. Los quindecimviri eran los guardianes de los libros sibilinos y brindaban recomendaciones rituales, siendo su función básica buscar la anuencia divina y sugerir ritos para obtenerla o volver a ganarla. ${ }^{1}$ No está de más señalar que las prácticas religiosas no eran monopolio de los magistrados, ya que éstos eran funcionarios públicos que debían su cargo a su prestigio social, el cual se reafirmaba gracias al ejercicio de las magistraturas religiosas que, si bien no formaban parte del cursus honorum de los personajes políticos más importantes, eran fuente de reputación. Los jefes de familia se encargaban del culto familiar y cualquiera podía realizar sacrificios y adorar a su dios preferido; los romanos eran tolerantes en cuanto a la aceptación de otros dioses y cultos, siempre y cuando no trajera problemas ni disturbios como las Bacanales del 186 a. C., o se realizaran prácticas que se creían excesivas como los sacrificios humanos. ${ }^{2}$ Estos magistrados se ocupaban de la

\footnotetext{
${ }^{1}$ J. H. W. G. Liebeschuetz, Continuity and Change in Roman religion, 1979, pp. 7-8. Jean Bayet, La religión romana, pp. 109-117.

2 James Rives, "Religion in the Roman empire" en Janet Huskinson (ed.), Experiencing Rome. Culture, Identity and Power in the Roman Empire, pp. 253-258.
} 
correcta ejecución de los rituales que el pueblo romano daba como conjunto a sus dioses, lo que tenía un carácter estatal y colectivo bastante marcado, con el fin de mantener la buena relación con los dioses.

Desde los primeros momentos de su existencia se resaltó el lazo entre Roma y los dioses. Los ejemplos de este vínculo son numerosos, por lo que solamente se destacan algunos: el origen prodigioso de los gemelos hijos de Marte, los auspicios de la fundación de la ciudad y de la elección de los reyes, la formación de las instituciones religiosas por Numa y otros sucesos afines que presagiaban la grandeza romana y que mostraban su colaboración con los romanos son contados en la historiografía romana como muestras del favor divino hacia Roma. ${ }^{3}$ Tras la instauración de la república, las señales propicias a Roma aumentaron y se notaron en eventos como la batalla del lago Regilo, la conquista de Veyes y la defensa de la ciudad en la invasión gala del 389 a. C. El libro V de Tito Livio se destaca por las reiteradas señales divinas que anuncian la victoria romana sobre su rival etrusca como la subida del agua del lago Albano, las palabras de un viejo arúspice veyense que vaticinaba el triunfo romano y la declaración del oráculo de Delfos a favor de los romanos. Además, marca un acto particular de los romanos: atraerse a los dioses vecinos mediante la adopción de su culto y la erección de templos en

John Scheid, "El sacerdote", en Andrea Giardina (ed.), El hombre romano, pp. 8283. En la sociedad romana primitiva, una función propia del paterfamilias era ser el representante de la familia ante los dioses y el sacerdote de los cultos familiares, por lo que había una habitación de la domus para tal efecto. Géza Alföldy, Historia social de Roma, p. 22. David Frankfurter, "Traditional Cult", en David S. Potter (ed.), A Companion to the Roman Empire, pp. 557-558. Los magistrados se encargaban del culto que Roma daba como Estado a los dioses y no intervenían en los cultos privados, pues cada quien adoraba al dios que quería. De ahí que los Decios necesitaran que los pontífices les dictaran las palabras adecuadas cuando decidieron sacrificarse para asegurar el éxito romano en la guerra latina de mediados del siglo IV y en la tercera guerra samnítica. Liv., VIII.10, X.28.

${ }^{3}$ Liv., I.4-8, I.18-21, I.55-56. Dion. Hal., Ant. Rom., I.85-87. Plut., Vit. Rom., XXVIII. 
su honor, para que, al pactar con ellos, obtuvieran su protección. Este libro también resalta las continuas intromisiones de los dioses a favor de Roma frente a los galos, los ejemplos de piedad hacia el culto y la mediación divina que libró a la ciudad de la penetración gala gracias a los graznidos de un ganso. ${ }^{4}$ La presencia de lo divino en la vida pública romana era grande y se reflejaba en templos, altares, sacrificios, sacerdotes, etcétera, que reiteraban la unión del mundo divino con el poderío romano. Así, los romanos se mostraban como los favoritos de las deidades y a éstas como las fuerzas detrás del éxito de las armas romanas que conquistaron el mundo. Salustio menciona que Aderbal, hijo de Masinisa, había dicho ante el senado: "Por su valor y por la voluntad de los dioses son grandes y poderosos; todo es inferior a ustedes y obedece sus deseos". 5 Ante el favor recibido, los romanos debían exhibir su lealtad a los dioses mediante las formas habituales y la ejecución de los ritos con cuidado y reverencia. Por ejemplo, existían los feciales que se ocupaban de validar las acciones bélicas y darles sanción religiosa. Los romanos se preocuparon por presentar sus guerras como justas, por lo que la anuencia divina era un elemento ideológico que validaba sus ambiciones. Esta participación de los dioses hizo que en el siglo I a. C. Dionisio de Halicarnaso expusiera las instituciones religiosas atribuidas al rey Numa y el cuidado en la celebración de ceremonias y sacrificios

para que a quienes desconocen la piedad romana, que los hombres de entonces la practicaban, no les resulte extraño que todas sus guerras alcanzasen el final más brillante. En efecto, se verá que todas ellas las hicieron por las causas y motivos más piado-

\footnotetext{
${ }^{4}$ Liv., V.15-16, 21-22, 46-47, 52.

${ }^{5}$ Sall., Iug., XIV.19: "Virtute ac dis uolentibus magni estis et opulenti, omnia secunda et obodoentia sunt". La cita latina de esta obra proviene de la Bibliotheca Scriptorum Graecorum et Romanorum Mexicana.
} 
sos y precisamente por eso tuvieron a los dioses propicios en los peligros. $^{6}$

Tal especial y evidente vínculo entre los dioses y Roma se utilizó como prueba fehaciente de la participación divina en la grandeza romana frente a los cristianos, pues éstos se mostraban renuentes a adorar a los dioses tradicionales. Esto era un punto de desencuentro que provocaba diversas reacciones de los paganos debido a los problemas relativos a la negativa cristiana de participar en el culto colectivo de los dioses del Estado. Tertuliano es consciente de ello cuando dedica una buena parte del Apologético a responder "aquel prejuicio que dice que los romanos, por mérito de su diligentísima religiosidad, han sido llevados a tal punto de grandeza que se apoderaron del mundo y, además, que los dioses existen porque prosperan más que otros quienes realizan aquellos deberes más que los demás". ${ }^{7}$ En el siglo III Minucio Félix en su Octavio relata que el pagano Cecilio le hacía ver al cristiano Octavio este lazo del Estado romano con los dioses. Le indica que el poder romano se basa en la adoración de los dioses y en la continuidad de sus cultos, y enfatiza que un hábito romano ha sido adoptar a las divinidades extranjeras: "así mientras adoptan los ritos

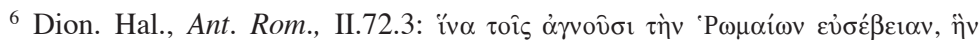

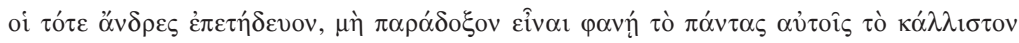

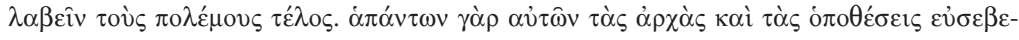

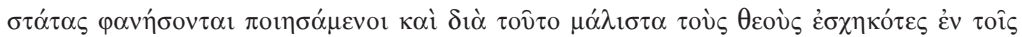

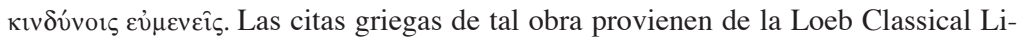
brary y las españolas de la Biblioteca Clásica Gredos. En contraste, la desatención hacia los cultos y las advertencias divinas provocaron pestes y hambres, lo que se remediaba con la correcta celebración de las ceremonias. Liv., I.31,V.14, V.32, VII-2-3, VII.27.

${ }^{7}$ Tert., Apol., 25.2: "quam provocat illa praesumptio dicentium Romanos pro merito religiositatis diligentissimae in tantum sublimitatis elatos, ut orbem occuparint, et adeo deos esse, ut praeter ceteros floreant qui illis officium praeter ceteros faciant". Las citas latinas de esta obra provienen de la Loeb Clasical Library. Mismo apunte en Tert., Ad nat., II.17.2.
} 
religiosos de todas las naciones, han merecido su dominio". 8 Señala que los ancestros pusieron atención a los sacrificios y los augurios, y enuncia algunos pasajes de la historia romana en los que la Gran Madre, los Dioscuros y Júpiter, entre otros, brindaron ayuda decisiva a los romanos. Por el contrario, el desprecio de los cultos y la burla a las señales provocaron desastres como Alia y los reveses de Claudio y Junio en la primera guerra púnica, el de Flaminio en Trasimeno y el de Craso en Carras. ${ }^{9}$ El auxilio divino no se hallaba solamente en el pasado, sino el presente también conocía sucesos parecidos. La Historia Augusta relata que Aureliano reprocha a los senadores su vacilación sobre la consulta de los libros sibilinos en una situación crítica, pues no era vergonzoso solicitar la ayuda divina, ya que los mayores habían tenido tal proceder en muchas guerras. Se menciona que, tras una batalla, "no hubiera ocurrido la victoria romana a no ser por la ayuda divina: después de la consulta de los libros y de las celebraciones de los sacrificios, los bárbaros fueron confundidos por ciertos prodigios y apariciones divinas". ${ }^{10}$

Esto es un rasgo destacado aun cuando el cristianismo tomó una posición favorable en el Estado romano y que Símaco resaltó en la célebre disputa sobre el altar de la Victoria a fines del siglo IV. En 384 Símaco pidió la reinstalación del altar y de los fondos para los cultos ante Valentiniano II, pues Graciano había quitado esos privilegios y renunciado al título de pontífice máximo dos años antes. Sabedor de que tales órdenes implicaban la dimisión del carácter oficial de los cultos

\footnotetext{
${ }^{8}$ Min. Fel., VI.3: "sic dum universarum gentium sacra suscipiunt etiam regna meruerunt". Las citas latinas de esta obra provienen de la Loeb Classical Library. Sobre tal actitud romana, vid. Georges Dumézil, La religion romaine archaïque, pp. 412-418.

${ }^{9}$ Min. Fel., VI-VIII.

${ }^{10}$ SHA. Aurel., 20.4-7: "denique nisi divina ope post inspectionem Librorum sacrificiorumque curas monstris quibusdam speciebusque divinis impliciti essent barbari, Romana victoria non fuiste". La cita latina de esta obra proviene de Loeb Classical Library.
} 
tradicionales como religión estatal, Símaco hacía estas demandas en nombre de la parte pagana del senado que deseaba que se conservara ese carácter y tuviera el apoyo económico del Estado. Por ende, aducía que Roma había llegado a una condición próspera gracias a sus ritos ancestrales:

Este culto sometió el orbe a mis leyes, estos ritos religiosos alejaron a Aníbal de mis murallas, a los sénones del Capitolio. ¿Para esto he sido preservada: para ser censurada anciana? Veré, cual sea, lo que se piensa que debe establecerse; empero, la enmienda en la vejez es tardía y ultrajante. ${ }^{11}$

Además, el prefecto decía que las malas cosechas en Roma se debían a la reglamentación que relegaba las antiguas ceremonias al olvido y que despreciaba la importante función de los sacerdotes y las vestales. Con esto señalaba que la adecuada disposición con los dioses no sólo se veía en los buenos resultados de las guerras, sino también en los asuntos internos del Estado. ${ }^{12}$ En pleno siglo VI, Zósimo se adhería a este pensamiento y culpaba al cristianismo de las desgracias del Imperio al marcar al gobierno de Constantino como el inicio del declive romano por su abandono de los antiguos cultos. Cuenta que el recelo de varios senadores romanos por dejar la antigua religión y sus tradiciones durante el mandato de Teodosio se debía a que "durante los ya casi mil doscientos años a lo largo de los cuales habían habitado la ciudad en observancia de aquéllas, ésta no había sido saqueada, mientras que si ahora cambiaban dichas creencias por otras ignoraban

\footnotetext{
${ }^{11}$ Symmachus, Rel., III.9-10: "Hic cultus in leges meas orbem redegit, haec sacra Hannibalem a moenibus, a Capitolio Senonas reppulerunt. Ad hoc ergo servata sum, ut longaeva reprehendar? Videro, quale sit, quod instituendum putatur; sera tamen et contumeliosa emendatio senectutis". Las citas latinas de esta obra provienen de la edición de Richard Klein.

${ }^{12}$ Idem, III.5. Sobre los aspectos en torno al altar como símbolo de cohesión y adhesión a la autoridad, cf. Santo Mazzarino, Storia sociale del vescovo Ambrogio, pp. 31-32.
} 
que sucedería". ${ }^{13}$ Los funestos efectos se evidenciaron con la amenaza de Alarico sobre Roma. Zósimo afirma que se había previsto reanudar los ritos ante tal contingencia, lo que el obispo de Roma presuntamente habría aceptado con la condición de que fueran en secreto. Los adivinos insistían que sólo tendrían efecto si eran públicos, lo cual no se aceptó; las ceremonias no se efectuaron y los dioses no protegieron a la Ciudad, que poco tiempo después fue presa de Alarico. ${ }^{14}$

Los romanos fueron plenamente conscientes de este lazo con los dioses durante toda su historia. Aunque sabían que la adquisición y el sostén del Imperio obedecían a diversos factores, no despreciaron la religión al considerarla un elemento primordial del orden y la cohesión social; al hacer esto conectaban el plano divino con los asuntos humanos. Para asegurar la hegemonía romana había que disponer de todos los medios posibles, lo que incluía la observación de los cultos; así, los romanos se presentaron a sí mismos como hombres muy religiosos. En su análisis de la constitución romana, Polibio, un admirador de ésta, exhibía su superioridad sobre la organización de otros pueblos. Al lado de las ventajas políticas innegables de su gobierno, destacaba a la religión tradicional como rasgo crucial del mismo:

Pero la diferencia positiva mayor que tiene la constitución romana es, a mi juicio, la de las convicciones religiosas. Y me parece

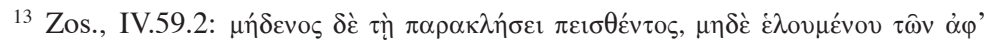

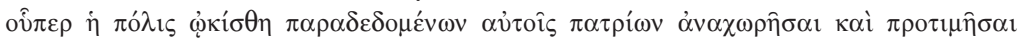

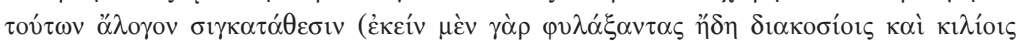

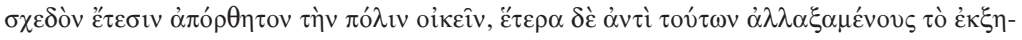
бó $\mu \varepsilon v o v ~ \alpha ̉ \gamma v o v \varepsilon i v)$. Las citas griegas de esta obra provienen de la Collection des Universités de France y las españolas de la Biblioteca Clásica Gredos.

${ }^{14}$ Zos., V.41.5-6. El mismo autor indica que la negativa de Graciano a portar el título de pontífice máximo y el retiro del apoyo a los cultos tradicionales fueron las causas de su destronamiento y muerte. IV.36 Además añoraba la época en que no existía la legislación de Teodosio que prohibía los sacrificios y la visita a los templos y en la cual se podían celebrar los ritos tradicionales. (Zos., IV.29.2) Sobre las leyes contra los cultos y la adivinación de Teodosio, vid. Charles Norris Cochrane, Cristianismo y cultura clásica, pp. 322-327. 
también que ha sostenido a Roma una cosa que entre los demás pueblos ha sido objeto de mofa: me refiero a la religión. Entre los romanos este elemento está presente hasta tal punto y con tanto dramatismo, en la vida privada y en los asuntos públicos, que ya es imposible ir más allá. ${ }^{15}$

Cicerón iba más lejos al afirmar que precisamente lo que mejor distinguía a los romanos de otros pueblos era su sentido religioso. Primero establecía un punto de apoyo para esta aseveración al preguntar: “¿quién, habiendo comprendido que los dioses existen, no se da cuenta de que por su voluntad nació, creció y se ha preservado este imperio tan grande?" Después de esto señala que los romanos no sobresalían más que los latinos, los fenicios, los griegos y los hispanos por su número, valor o ingenio, "sino que hemos superado a todos los pueblos y naciones en piedad, sentido religioso y en este único saber: hemos reconocido que todo es regido y gobernado por la voluntad de los dioses". ${ }^{16}$

En esta óptica se debía atraer a las deidades propicias a Roma y no minimizar la obediencia religiosa como un factor explicativo que era consecuente consigo mismo. En su inicio, Roma no era una ciudad que se diferenciara mucho de sus vecinas y nada indicaba que tendría un futuro mejor que ellas, si a esto se añade que fue presa de conflictos internos y amenazas exteriores, realmente era sorprendente su evolución

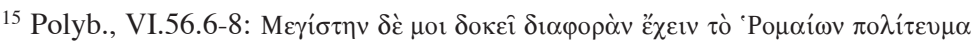

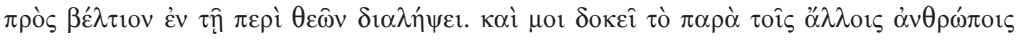

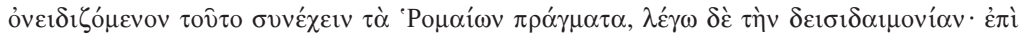

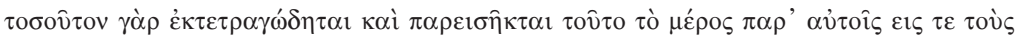

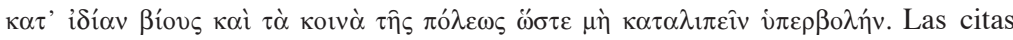
griegas de esta obra provienen de la Collection des Universités de France y las españolas de la Biblioteca Clásica Gredos.

${ }^{16}$ Cic., Har. Resp., 19: “¿quis [...], cum deos esse intellexerit, non intellegat eorum numine hoc tantum imperium esse natum et auctum et retentum? [...] sed pietate ac religione atque hac una sapientia quod deorum numine omnia regi gubernarique perspeximus, omnis gentis nationesque superavimus". La cita latina de esta obra proviene de la Scriptorum Classicorum Bibliotheca Oxoniensis.
} 
que la hizo conquistar gran parte del mundo conocido. Como varios pueblos conquistadores que súbitamente irrumpen, los romanos sintieron que su hegemonía no solamente debía ser expuesta y justificada por causas humanas como la constancia, el valor y la capacidad, sino también por motivos divinos; si algún pueblo merecía ser el favorito de los dioses debía ser Roma, lo que daba mayor peso a su mando. Con motivo del episodio en que se afirmaba que la diosa Juno de Veyes había consentido su traslado a Roma, Plutarco aseguraba:

Pero los que insisten y defienden el milagro, encuentran un abogado muy importante en la fortuna de la ciudad; pues difícilmente se llega, partiendo de un pequeño e insignificante principio, a tanta gloria y poder sin la continua ayuda de un dios con muchas y grandes manifestaciones. ${ }^{17}$

La repetición de los cultos era fundamental para que conservara esa condición y fue un rasgo constante en la historiografía romana. Dionisio de Halicarnaso alude a la mesura y sencillez de los sacrificios y las ceremonias romanas "que en su mayor parte, si no todos, han permanecido hasta nuestros días realizados según la manera antigua", para después afirmar que le gustaba "que permanecieron en sus costumbres ancestrales sin apartarse de sus antiguos ritos para cambiarlos por una magnificencia jactanciosa". ${ }^{18}$ Siglos después, el emperador Juliano,

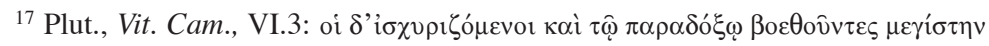

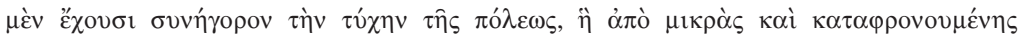

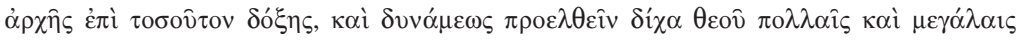

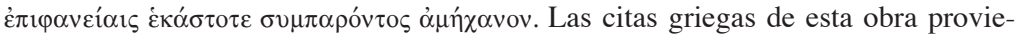
nen de la Collection des Universités de France y las españolas de la Biblioteca Clásica Gredos.

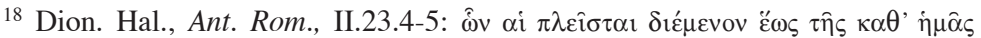

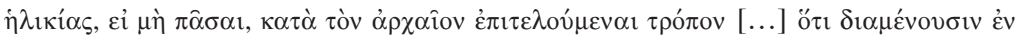

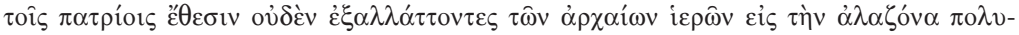
$\tau \varepsilon ́ \lambda \varepsilon 1 \alpha v$. Una observación similar da Tito Livio cuando señala que, durante mucho tiempo, el agradecimiento a los dioses se mostraba más con piedad que con objetos ostentosos (Liv., III.57). Aunque no faltan las críticas por el olvido de las antiguas ceremonias y costumbres por la adopción de hábitos extranjeros (Liv., VIII.11). 
que se consideraba un ferviente seguidor y restaurador de los viejos cultos, decía que sus antepasados, refiriéndose a los romanos, desde los tiempos de Numa, habían persistido en su celo religioso característico y en la piedad hacia los dioses, lo cual aseguraba su generosidad, pues eran inteligentes y religiosos por naturaleza. ${ }^{19}$

Se ha discutido hasta qué punto los romanos creían y tomaban en serio estas cuestiones. Por ejemplo, se ha destacado que la postura contraria de Cicerón hacia las leyes religiosas de Clodio obedecía a lo que creía abusos de los tribunos, planteando que la modificación de las leyes, más que provocar el descontento divino, generaría violencia política. La posición de Cicerón se basaba más en la prevención de las divisiones internas que en el temor al castigo divino por la conducta de Clodio. Igualmente, había nobles romanos que pensaban que la justicia divina era un asunto remoto, aunque la historia brindara numerosos ejemplos de lo contrario, y el pueblo confiaba más en Pompeyo que en los dioses para asegurar la provisión de grano en Roma. ${ }^{20}$ Empero, tales posturas no ne-

\footnotetext{
${ }^{19}$ Julian., Or., XI. 155d.

${ }^{20}$ Liebeschuetz, op. cit., pp. 30-31. También señala que los escrúpulos religiosos se utilizaban para obstruir elecciones, aunque era poco frecuente. Por su parte, Dumézil admite la posibilidad de que el arúspice tomara su decisión de acuerdo a criterios políticos (op. cit., pp. 579-581). Polibio creía que las formas religiosas servían para mantener sujetas a las masas que eran irracionales y violentas (Polyb., VI.56.9-11). Para este tema vid. G. E. M. de Ste. Croix, La lucha de clases en el mundo griego antiguo, 1988, pp. 401-402. Aunque estas prácticas mantenían la confianza pública y ayudaban a evitar el pánico en momentos de crisis, no excluían que se tomaran medidas para asegurarse el bienestar por medios humanos. Brunt resalta la importancia de la participación popular para que se le diera a Pompeyo el mando contra los piratas y aliviar la escasez de grano en Roma [P. A. Brunt, "La plebe romana", en Moses Finley (ed.), Estudios de Historia Antigua, p. 108]. Igualmente, en su discurso contra Lépido en el senado en 77 a. C., el cónsul Fi-
} 
gaban la religión tradicional, ya que el respeto a la autoridad ancestral aseguraba la continuidad del ritual. La actitud de Cicerón sobre la adivinación aclara esto, pues la primera parte de su tratado sobre el tema expone los argumentos a su favor, mientras que la segunda exhibe las razones opuestas. Aunque en otros trabajos señala que los auspicios habían salvado al Estado de decisiones malas, él no cree en la adivinación a la que califica de superstición. Indica que ésta debe descartarse porque se apodera de las mentes de los hombres débiles, puesto que:

con eliminar la superstición no se elimina la religión. Pues, por una parte, es propio del sabio defender las instituciones de los mayores conservando los ritos sagrados y las ceremonias; por otra parte, la belleza del universo y el orden de los cuerpos celestes nos obligan a confesar que existe un ser superior y eterno, digno de ser honrado y admirado por el género humano, por lo cual, así como debe inclusive propagarse la religión que está unida al conocimiento de la naturaleza, así deben ser arrancadas todas las raíces de la superstición. ${ }^{21}$

Que se tuvieran dudas sobre ciertas prácticas no significaba necesariamente que se negaran. El que la primera parte de esta

lipo decía que se debía realizar acciones fehacientes contra aquél y no solamente expedir decretos y esperar las palabras de los adivinos (Sall., Hist., II.3). Esto no evitaba expresiones que vinculaban el descuido del culto con el ámbito cotidiano. En el Satiricón un personaje decía que en el pasado la piedad sencilla y sincera con los dioses propiciaba las lluvias, mientras que su desatención provocaba malas cosechas (Sat., 44).

${ }^{21}$ Cic., Div., II.49: "Nec [...] superstitione tollenda religio tollitur. Nam et maiorum instituta tueri sacris caerimoniisque retinendis sapientis est, et esse praestantem aliquam aeternamque naturam, et eam suspiciendam admirandamque hominum generi pulchritudo mundi ordoque rerum caelestium cogit confiteri". Las citas latinas y españolas de esta obra provienen de la Bibliotheca Scriptorum Graecorum et Romanorum Mexicana. Para Cicerón la existencia de los dioses era innegable, aunque esto no significaba que compartiera la visión popular y mítica de ellos. Si bien no la desechaba del todo, su acercamiento era por vía filosófica al ver el orden del universo que reclamaba una inteligencia detrás de él (Har. Resp., 19, Nat. D., II.73-153). Cf. Francisco Pina Polo, Marco Tulio Cicerón, pp. 200-203. 
obra de Cicerón presentara las evidencias en favor de la adivinación muestra que había personas convencidas de esa posibilidad y que la defendían con argumentos filosóficos extraídos del estoicismo, escuela que también juega un papel preponderante en la comprobación de la existencia de los dioses en su diálogo Sobre la naturaleza de los dioses. En un mundo en que la frontera entre lo natural y lo sobrenatural no estaba clara, había gente que se sentía cerca de los dioses y otras fuerzas espirituales mediante las normas habituales de piedad, lo que incluía a letrados e incultos por igual. Las numerosas alusiones a advertencias divinas o sobrenaturales en la vida de insignes hombres que recogen escritores como Plutarco y Suetonio, quienes tenían la mejor preparación de la época, sugieren que estas creencias tenían visos de verosimilitud para las personas de ese tiempo. Keith Hopkins ha apuntado que por muchos años la historiografía descuidó y dejó en un plano secundario el estudio de estas ideas por considerarlas supersticiones propias de etapas irracionales o de grupos incultos. Los fenómenos desconocidos o poco conocidos hacían que los romanos buscaran controlarlos mediante encantamientos y sacrificios, al igual que entenderlos mediante la interpretación de sueños. ${ }^{22}$ Lo inexplicable, impredecible, mágico y sobrenatural estuvo presente en la sociedad romana y cubría casi toda esfera y etapa de la vida. Este ambiente permeó todos los grupos sociales y a personas con distintos antecedentes, algunos intentaban distinguir cosas que otros no se molestaban en hacer. El militar e historiador Amiano escribió la última gran obra histórica sobre Roma en el siglo IV que da cuenta de la

\footnotetext{
${ }^{22}$ Keith Hopkins, Conquistadores y esclavos, pp. 266-277. Esto no quita que algunos se burlaran de la concepción popular de los dioses, que tuvieran objeciones serias hacia la existencia y providencia divinas, aunque sabían que eran la minoría, y que notaran la simulación y charlatanería de algunos en sus prácticas religiosas como medio de vida. Juv., II.110-116, 149-152. Luc., J. Conf., 9-25. J. Tragic., 22-53. App., Met., VIII.27. Cf. Catherine Salles, Los bajos fondos de la Antigüedad, pp. 240-242.
} 
persistencia de estas creencias en la sociedad de su tiempo. En su relato hay varias menciones sobre la confirmación de predicciones en distintos personajes, así como la represión imperial hacia las prácticas adivinatorias y mágicas, especialmente cuando se hacían sobre la vida del emperador. En este clima tenso, Libanio fue acusado de realizar prácticas adivinatorias, incluidas algunas en una intriga contra el príncipe Valente. El rétor negó toda intervención en este hecho, pero reconocía que en ocasiones recurría a prácticas mágicas para aliviar su salud aquejada por conjuros de sus enemigos. ${ }^{23}$ Por su parte, Amiano asevera que los dioses tienen varios modos de comunicar sus deseos a los hombres, por lo que, a quienes señalan los errores de vaticinios, apunta que no es razón para negar la adivinación, pues "a veces el gramático ha hablado toscamente, el músico ha cantado de manera inadecuada y el médico ha ignorado algún remedio, pero no por ello no subsisten la gramática, la música y la medicina". ${ }^{24}$

El que los autores conocieran la función social de la religión y su uso político no quiere decir que la religión no tuviera un valor en sí. La relación entre hombres y dioses se basaba en el intercambio de dones y el cumplimiento recíproco de los términos acordados, lo cual excluía temblar o hincarse ante los dioses como si se fuera un esclavo. Por esto, había personajes cultos que tenían sus reservas, cuando no rechazo, hacia algu-

\footnotetext{
${ }^{23}$ Amm. Marc., 28.1.19-29, 29.1-2. Lib., I.172-178, 249. Las leyes contra la astrología y la adivinación sobre el emperador muestra el convencimiento de estas artes, su persistencia y el temor a ellas. Cf. A. A. Barb, "La supervivencia de las artes mágicas", en Arnaldo Momigliano (ed.), El conflicto entre el paganismo y el cristianismo en el siglo IV, pp. 117-143. Franz Cumont, Las religiones orientales y el paganismo romano, pp. 143-168.

${ }^{24}$ Amm. Marc., 21.1.13: "sufficiet dici, quod et grammaticus locutus interdum est barbare, et absurde cecinit musicus, et ignoravit remedium medicus: sed non ideo nec gramatica nec musica nec medicina subsistit". Las citas latinas de esta obra provienen de la Loeb Classical Library. Para un análisis de estas creencias en la literatura de este tiempo, vid. Arnaldo Momigliano, "Las creencias religiosas populares y los historiadores", en Ensayos de historiografía antigua y moderna, pp. 128-139.
} 
nos rasgos de la religión popular. También criticaban la visión absurda y distorsionada de los dioses al presentarlos como coléricos, vengativos y caprichosos, cuando lo piadoso era considerarlos benévolos y justos; simultáneamente, se reprochaba la excesiva familiaridad con los dioses, pues debía guardarse una distancia respetuosa. A pesar de ello, los letrados respetaban las normas tradicionales de piedad al razonar que había aspectos oscuros sobre las divinidades; siendo lo más sensato continuar los cultos ancestrales, ya que podían poseer un núcleo de verdad. ${ }^{25}$ Aunque hubiera engaños y relatos falsos, eso no implica que las intervenciones divinas y prodigios que registraba el pasado no pudieran haber ocurrido, pues los dioses podían haber realizado esas acciones en una etapa que los hombres estaban más cercanos a ellos. Ante lo difícil de dilucidar la naturaleza de lo divino, no estaba de más observar los viejos ritos avalados por la tradición y acercarse a los dioses de todos los modos posibles. Por ello Cicerón separaba a la religión de la superstición: a la primera debía cuidarse, a la segunda combatir. Decía que ésta "difundida a través delas naciones, ha oprimido las almas de casi todos y se ha apoderado de la debilidad de los hombres [...] En efecto, me parecía que yo sería muy útil tanto para mí mismo como para mis conciudadanos, si la eliminaba por completo". ${ }^{26}$ Por ello, algunos tenían una actitud de observación atenta y reconocimiento prudente acerca de los fenómenos sobrenaturales. Al comentar los sucesos prodigiosos que rodearon la toma de Veyes, Tito Livio indicaba cuán temerario era tomar una postura tajante sobre si sucedieron o no tales eventos. Dice que "en cosas tan antiguas tendría bastante con tomar lo verosímil por lo verdadero, en cuanto a estas cosas más aptas para la

\footnotetext{
${ }^{25}$ Paul Veyne, "El Imperio romano", en Phillipe Ariès y Georges Duby (eds.), Historia de la vida privada, v. 1, pp. 210-212.

${ }^{26}$ Cic., Div., II.148-149: "fusa per gentis, oppresit omnium fere animos atque hominum imbecillitatem occupavit [...] Multum enim et nobismet ipsis et nostris profuturi videbamur, si eam funditus sustulissemus".
} 
exhibición del teatro, el cual goza con lo asombroso, que para la credibilidad no vale la pena afirmarlas ni refutarlas". ${ }^{27} \mathrm{Plu}-$ tarco actúa de modo parecido cuando trata ese mismo hecho $\mathrm{y}$ otros parecidos que acontecieron en distintos periodos $\mathrm{y}$ lugares para señalar la postura adecuada que, a su juicio, tenía que seguirse ante dicha cuestión:

Sin embargo, en cuestiones semejantes tanto el exceso de credulidad como el exceso de desconfianza es peligroso, a causa de la debilidad humana, que no tiene límite ni se controla a sí misma, sino que tan pronto se deja arrastrar hacia la vana superstición como hacia la indeferencia y el desprecio de las cosas divinas. La cautela y el "nada en exceso" son lo mejor. ${ }^{28}$

Este proceder reflexivo era un punto de equilibrio entre la credulidad grosera y el desprecio insolente; además, contemplaba el acatamiento a las normas tradicionales de piedad.

Sobre tal aspecto, algunos estudiosos han indicado que la religión antigua tenía varias formas de comunicarse con lo divino, pero no constituían un sistema coherente. La religión se basaba en prácticas como la plegaria y el sacrificio que creaban

${ }^{27}$ Liv., V.21.9: "in rebus tam antiquis, si quae similia ueris sint pro ueris accipiantur, satis habeam; haec ad ostentationem scenae gaudentis miraculis aptiora quam ad fidem neque adfirmare neque refellere est operae pretium". Las citas latinas de esta obra provienen de la Scriptorum Classicorum Bibliotheca Oxoniensis.

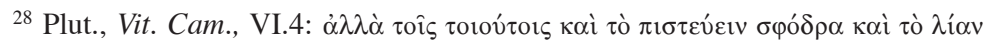

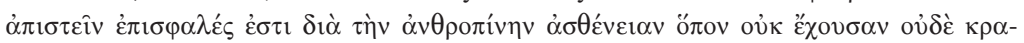

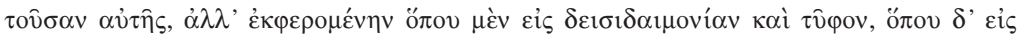

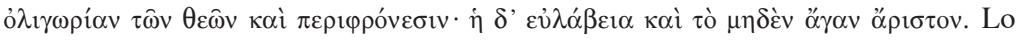
que no evitaba que considerara las etapas pasadas como más propensas a la simplicidad de la mente. Plut., Vit. Num., XV. Los cristianos repitieron esto en su polémica contra los gentiles. Tert., Ad nat., II.12.33. Min. Fel., XX.3. XXIV.1. Clem. Al., Protr., X.99.2. Prudent., Perist., I.40-55, 145. Cabe señalar que, por mucho recelo que los filósofos tuvieran hacia los cultos, raras veces se negaban a participar en ellos, cosa que los cristianos sí hacían. Además, los filósofos no solían interesarse por divulgar sus ideas entre el común de la gente, pues consideraban que no tenían la preparación ni el deseo de profundizar en el saber, por lo que era absurdo dirigirse a ellos. Cf. Celso, El discurso verdadero, VI.6.8. Porph., Abst., I.27.1. 
vínculos entre los dioses y los hombres para que éstos obtuvieran el favor de aquéllos. La religión antigua no tenía credos ni doctrinas, ya que los rituales eran el centro de la práctica; lo que importaba era la participación colectiva, no la creencia. Igualmente, la religión no era el único medio para estudiar la divinidad, pues la filosofía y el mito también se ocupaban también de ello y no confluían forzosamente en los cultos ni se relacionaban con ellos. Debido a esto, tales medios no constituían un sistema unificado que diera una visión unitaria de lo divino, sino que cada uno tenía sus propias dinámicas y métodos que ocasionaban actitudes que pocas veces eran congruentes unas con otras, ni buscaban serlo; para cada situación particular había diferentes juicios y criterios. ${ }^{29}$ Aunque la filosofía socavara la concepción popular de los dioses, de igual forma sirvió para encontrar vías que analizaran lo divino y discutir las tradiciones de cada pueblo bajo la luz de las ideas filosóficas, siendo el estoicismo y el neoplatonismo las principales corrientes que apuntaron hacia ese objetivo. Estas escuelas dieron elementos explicativos para sustentar la adivinación y la creencia de los dioses, así como aclarar alegóricamente los relatos poéticos para extraer sentidos ocultos y profundos. El método alegórico fue aprovechado por los cristianos para acercarse a sus propios textos sagrados y a la literatura de su tiempo, por lo que el neoplatonismo fue un influjo decisivo en varios pensadores cristianos. Si bien el estoicismo suministró razones para sustentar la adivinación y utilizaba el método alegórico, el neoplatonismo tenía un matiz religioso más acentuado y adoptó la teúrgia, los oráculos caldeos, la

\footnotetext{
${ }^{29}$ Liebeschuetz, op. cit., pp. 33-37. Rives, "Religion in the Roman empire", en Huskinson, op. cit., pp. 249-252. Hopkins, op. cit., pp. 251, 277-279. Jean-Pierre Vernant, Entre mito y política, p. 100. Peter Brown, El primer milenio de la cristiandad occidental, pp. 42-43. Esta falta de unidad entre las diversas formas de estudiar lo divino fue utilizado por Tertuliano y Agustín para negar el intento pagano de justificar la existencia de los dioses y las inconsistencias de conciliar estas vías usando la obra de Varrón y su división tripartita de la teología. August., De Civ. D., VI-VII. Tert., Ad nat., II.1-16.
} 
poesía órfica, la teosofía hermética, y diversas prácticas ascéticas y contemplativas. ${ }^{30}$ Esta postura ecléctica fue más usual cuando el cristianismo empezó a ganar más adeptos y a desechar las posturas que no concordaran con sus doctrinas. Al tener el apoyo estatal y adquirir una posición predominante, se volvió un rival que no admitía más verdad que la suya, lo que motivó a los paganos a dejar sus diferencias y aprovechar todos los medios disponibles para validar su visión de las cosas.

En la misma línea, se ha asegurado que la religión romana no tenía ningún vínculo con la moral y que solamente se preocupaba por la correcta ejecución de las ceremonias y los ritos, reduciéndolo todo a un mero carácter formal. Los autores cristianos concentraron sus esfuerzos en responder a los cuestionamientos y los ataques paganos por su negativa a adorar a los dioses y participar en el culto público mediante diversos argumentos. Empero, esta parte apologética estaba separada de las secciones encargadas de la moral y la filosofía. Lactancio recalcó la disociación de la religión con los otros dos campos al expresar que los sacrificios eran actos repetitivos y vanos que influían poco en la vida de las personas y no brindaban pautas de conducta que conllevaran el mejoramiento de las costumbres. Decía que los viejos cultos no buscaban la verdad, sino únicamente la participación ritual que no exigía un convencimiento pleno de la persona hacia la religión, por lo que no daba ningún beneficio. Debido a esto, en la religión oficial, la gente iba, sacrificaba y se retiraba tal y como llegaba sin brindar algún tipo de reflexión ni haber recibido directriz o consuelo. Dicha religión no repercutía en la con-

\footnotetext{
${ }^{30}$ Peter Brown, The world of Late Antiquity. From Marcus Aurelius to Muhammad, pp. 74-75. Averil Cameron, El mundo mediterráneo en la Antigüedad tardía (395-600), pp. 224-225. Werner Jaeger, Cristianismo primitivo y paideia griega, pp. 71-72. E. A. Ramos Jurado, "Mito y religión en la filosofía griega a fines del mundo antiguo", en José Luis Calvo Martínez (ed.), Religión, Magia y Mitología en la Antigüedad clásica, pp. 224-235. Algunos pasajes muy elogiosos de Agustín hacia los neoplatónicos en Conf., VII.9-13, VIII.2-3 y De Civ. D., VIII.1, 5-12. X.2, 23.
} 
ducta moral de los hombres y éstos no aprendían nada sobre la vida y las cosas divinas. ${ }^{31}$ Para los cristianos era totalmente reprensible esa falta de trato entre la moral y los cultos, y lo interpretaban como desinterés del aparato religioso por relacionarse con aspectos éticos que se plasmaran en el vínculo del hombre con Dios y con otros hombres. En esta línea, el acento puesto en la ejecución escrupulosa de ceremonias y sacrificios no conllevaba un compromiso que implicara el bienestar moral de individuo, con lo cual la religión antigua se reducía a una acción vacía, repetitiva y mecánica. Por ello, Agustín recriminaba lo que consideraba falta de atención de la religión tradicional hacia las cuestiones éticas y su excesiva relación con prácticas que creía inmorales e idolátricas, y que se llevaban a cabo frente a todos en los circos, teatros y anfiteatros. En medio de una sociedad que creía volcada a la caza de riqueza, gloria y placer, indicaba que

sin embargo, concernía a los dioses que consultaban no ocultar los preceptos de una buena vida a los pueblos que les rendían culto, sino ofrecerlos con un señalamiento claro; también convenir por medio de los adivinos y censurar a quienes cometen faltas, amenazar abiertamente con castigos a los que realizan males y prometer recompensas a quienes viven rectamente. ${ }^{32}$

Pese a los reclamos cristianos, el mundo antiguo no desconocía que la piedad hacia los dioses podía ejercer una buena in-

\footnotetext{
${ }^{31}$ Lactant., Div. Inst., IV.3.1-2. V.21.8.

32 August, De Civ. D., II.4: "Verum tamen pertinebat ad consultores deos vitae bonae preacepta non occultare populis cultoribus suis, sed clara praedicatione praehere, per vates etiam convenire atque arguere peccantes, palam minari poenas male agentibus, praemia recte viventibus polliceri". La cita latina de esta obra viene de la Bibliotheca Scriptorum Graecorum et Romanorum Teubneriana. Igualmente destaca esto en los siguientes parágrafos del mismo libro. Para Brown, uno de los mayores méritos del cristianismo fue agrupar elementos como el rito, la teología y la ética, dispersos en el mundo antiguo, en un solo sistema religioso ( $E l$ primer..., p. 39). Una visión opuesta en Frankfurter, "Tradicional Cult", en Potter, op. cit., pp. 544-546.
} 
fluencia en los participantes del culto. Había autores que percibían que el sentimiento religioso y la creencia en los dioses podían tener un influjo positivo en el proceder humano. En este sentido, Polibio decía que "Aprender a ser sinceros con los dioses es un aguijón que nos incita a decirnos mutuamente la verdad". ${ }^{33}$ Asimismo, hubo escritores que no vacilaban en manifestar su desaprobación sobre las súplicas impías que algunos dirigían a los dioses. Uno de ellos fue Petronio, quien denunciaba sin rodeos que en su tiempo muchos hombres "ni siquiera piden una mente buena y una buena salud, sino inmediatamente antes de tocar el umbral del Capitolio, uno promete un don si entierra a un pariente rico, otro si desentierra un tesoro, otro si llega a salvo a los treinta millones de sestercios". ${ }^{34}$ Siglos después, Porfirio indicaba que el talante con que se iba a sacrificar y a participar en los cultos públicos no era algo secundario o insignificante, sino que era crucial para la buena y apropiada relación con los dioses. Por ello, asevera que quien se acercara a los dioses debía "sacrificar con una conducta limpia, ofreciendo a los dioses los sacrificios que les son gratos", para posteriormente criticar a quienes "van a los sacrificios sin tener el alma limpia de maldades, consideran que no tiene mayor importancia, como si la divinidad no se alegrara especialmente por el hecho de que el rasgo más divino que en nosotros hay se encuentre en estado de pureza, por serle connatural a su propia índole". ${ }^{35}$ No obs-

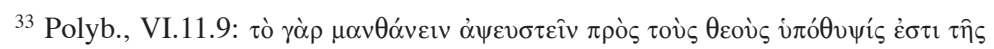

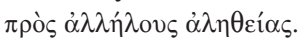

${ }^{34}$ Petr., Sat., 88: "Ac ne bonam quidem mentem aut bonam valetudinem petunt, sed statim antequam limen Capitolii tangant, alius donum promittit, si propinquum divitem extulerit, alius, si thesaurum effoderit, alius, si ad trcenties sestertius salvus pervenerit". La cita latina y la española de esta obra vienen de la Bibliotheca Scriptorum Graecorum et Romanorum Mexicana. Mismo reproche en Pers., II.614. Luc., Icar., 25.

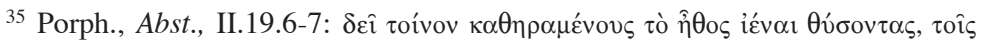

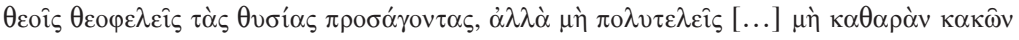


tante, a pesar de estas reflexiones, no había un código ético de conducta sancionado por la religión, pues los cultos no brindaban normas que los adoradores debían seguir al no ser su principal objetivo. La religión oficial consistía en sacrificios, ofrendas y festivales que enmarcaban eventos importantes en la vida cívica y que buscaban mantener el bienestar de la ciudad. El vínculo que tenían los hombres con los dioses era de respeto y gratitud que le daba un ser inferior a su superior, lo cual quedaba demostrado en el cumplimiento de los ritos. Debido a esto, se ha dicho que esta relación estaba modelada en las relaciones patrono-cliente de la sociedad romana en que se ofrecía algo a las deidades si éstas cumplían con su parte. ${ }^{36}$ En esta línea, Cicerón decía que se pedía riqueza y comodidades a los dioses, pero no virtudes ni sabiduría, las cuales se obtenían por méritos propios. Sobre esto, expresa que "llaman Óptimo y Máximo a Júpiter por estas razones: no porque nos hace justos, moderados, sabios, sino porque nos hace salvos, incólumes, opulentos, acaudalados". ${ }^{37}$

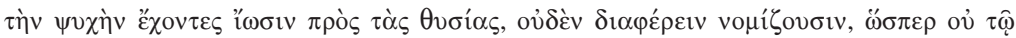

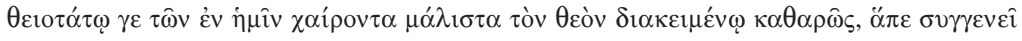

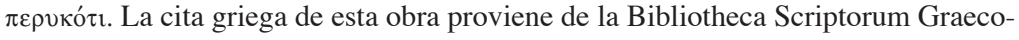
rum et Romanorum Teubneriana y la española de la Biblioteca Clásica Gredos.

${ }^{36}$ Veyne, op. cit., pp. 206-210. Vernant, op. cit., pp. 108-109. Frankfurter, en Potter, op. cit., pp. 557-558. Empero, se ha remarcado que, aunque la religión antigua no tenía otro lazo más que con el rito y la ceremonia, no era totalmente indiferente a la conducta humana, pues los dioses aprobaban las virtudes y reprobaban el vicio. Asimismo, esperaban que los hombres fueran piadosos y trataran de imitar sus cualidades en cuanto podían; además, se divinizaban virtudes y algunos delitos tenían alcances religiosos. Liebeschuetz, op. cit., pp. 41-53.

${ }^{37}$ Cic., Nat. D., III.87: "Iovemque optumum et maxumum ob eas res apellant: non quod nos iustos, temperatos, sapientes efficiat, sed quod salvos, incolumis, opulentos, copiosos". Las citas latinas y españolas de esta obra provienen de la Bibliotheca Scriptorum Graecorum et Romanorum Mexicana. Otros autores señalan que se pedía todo tipo de bienes a los dioses y que si éstos no los daban no tenía sentido adorarlos. Pers., II.41-47. Luc., J. Tragic., 18. Bis Acc., 2. Sacr., 2. M. Aur., IX.40. Jul., Gal., 138 c-d. 
No obstante, la validez de la religión antigua no descansaba en estos detalles, sino en la celebración adecuada de los ritos y las ceremonias que aseguraba la buena relación de los dioses con el Estado romano, resultando éste directamente beneficiado con tal vínculo. Esas formas pueden reunirse bajo la denominación de tradición, para lo cual conviene recurrir a la idea de tradición según Eric Hosbawm:

conjunto de prácticas, regidas normalmente por reglas manifiestas o aceptadas tácitamente y de naturaleza ritual o simbólica, que buscan inculcar ciertos valores y normas de comportamiento por medio de la repetición, lo que implica de manera automática una continuidad con el pasado. ${ }^{38}$

La religión se basada en la autoridad de la tradición ancestral celosamente custodiada y transmitida de padres a hijos a través del tiempo, lo que establecía el criterio primordial de aceptación. Uno de los mejores exponentes de este pensamiento es Cicerón en su Sobre la naturaleza de los dioses. Este diálogo expone las principales pruebas del epicureismo y el estoicismo sobre la naturaleza de lo divino y sus implicaciones. En la obra el pontífice máximo Cota agradece la defensa realizada de la existencia de los dioses por el estoico Balbo, pero aclara que sus argumentos le parecen limitados. Por ejemplo, alega que no puede probarse la existencia de los dioses utilizando la idea de la providencia, pues había numerosos casos en que hombres buenos y virtuosos sufrían injusticias, y los malos llevaban una vida placentera. ${ }^{39}$ Ante lo débil de esas razones, dice que su defensa de la religión romana y su creencia en

\footnotetext{
${ }^{38}$ Eric Hobsbawm, "La invención de la tradición”, en Eric Hobsbawm y Terence Pranger (eds.), La invención de la tradición, p. 8.

${ }^{39}$ Cic., Nat. D., III.80-84.
} 
los dioses no se basan en razonamientos filosóficos como su interlocutor estoico Balbo, sino en la autoridad de la tradición romana. Sobre las prácticas religiosas, Cota claramente indica que las "defenderé siempre y siempre las he defendido, y de aquella opinión que recibí de nuestros mayores sobre el culto de los dioses inmortales, jamás el discurso de algún docto o indocto me apartará". ${ }^{40}$ Para él, los pontífices máximos tenían más autoridad religiosa para influir en sus opiniones que las disertaciones estoicas. Así, la tradición era un elemento esencial de la preservación de la religión, ya que en el mundo clásico la noción de antigüedad estaba relacionada con lo venerable y lo verdadero.

Además, la religión era una forma importante de cohesión e identidad social y los romanos la vieron como componente primario de su legado y de su deseo de llevar una óptima relación con los dioses. En el caso romano esto cobraba mayor significación, pues los dioses jugaban un papel crucial en su poder y expansión; así, debía mantenerse esta unión mediante los preceptos tradicionales. Por ello, la ejecución de las ceremonias y la preservación de las instituciones religiosas eran fundamentales para la dicha de Roma. En esta lógica, Cota insiste en recordarle a Balbo que

Rómulo con los auspicios, Numa con el establecimiento de las ceremonias sagradas echaron los fundamentos de nuestro Estado, el cual sin duda nunca habría podido ser tan grande sin el sumo favor de los dioses inmortales [...] Pues de ti, un filósofo, debo recibir la demostración de la religión; a nuestros padres creerles sin ninguna demostración. ${ }^{41}$

${ }^{40}$ Cic., Nat. D., III.2.5: "Ego vero eas defendam semper semperque defendi, nec me ex ea opinione quam a maiorubus accepi de cultu deorum inmortalium ullius umquam oratio aut docti aut indocti movebit".

${ }^{41}$ Idem, III.2.6: "mihique ita persuasi, Romulum auspiciis Numam sacris constitutis fundamenta iecisse nostrae civitatis, quae numquam profecto sine summa placatione deorum inmortalium tanta esse potuisset [...] A te enim philosopho rationem accipere debeo religiones, maioribus autem nostris etiam nulla ratione 
La tradición se volvía el criterio cardinal para definir lo verdadero o, al menos, lo verosímil, ya que contaba con la sanción y el prestigio de la antigüedad, y también servía como factor de cohesión e identidad de un grupo humano. El aparato religioso era la base firme que sostenía la creencia en los dioses y la comunicación con ellos frente a las diversas argucias filosóficas que discutían lo divino, que a menudo se contradecían entre sí, y que llegaban a negar la existencia de las deidades o la posibilidad de acercarse a ellas. Debido a esto, no brindaban certeza alguna y socavaban uno de los pilares del sistema romano, lo cual era inaceptable. Aunque la razón filosófica pudiera defender la creencia en los dioses, la tradición no admitía discusión por su carácter antiguo. Así, por ejemplo, ante los problemas por definir de quién recibió el nombre el lago Curcio, Tito Livio señala que no habría ahorrado trabajo "si alguna vía llevara a la verdad, pero la tradición de los sucesos debe mantenerse cuando la antigüedad elimina la confianza segura y el nombre del lago es más distinguido por este relato más reciente". ${ }^{42}$

Esta línea de pensamiento se utilizó para hacer frente a las objeciones cristianas sobre los cultos tradicionales. Minucio Félix recoge los argumentos paganos para defender la religión antigua en boca de Cecilio. Este personaje indica los problemas del estudio de lo divino: si la naturaleza creó todo, si los elementos se combinaron para dar forma y sustentar todo cuanto existe, si todo ser consiste en la mezcla de elementos natu-

reddita credere". En otra obra, Cicerón hace decir a Escipión, sobre el relato del origen divino de Rómulo y Remo, que "concedamos, en efecto, a la tradición de los hombres, sobre todo a una, no sólo inveterada sino también sabiamente transmitida por nuestros mayores" (concedamus enim famae hominum, praesertim non inveteratae solum, sed etiam sapienter a maioribus proditae). Cic., Rep., II.4. La cita latina y la española de esta obra provienen de la Bibliotheca Scriptorum Graecorum et Romanorum Mexicana.

${ }^{42}$ Liv., VII.6.6: "si qua ad uerum uia inquirentem ferret: nunc fama rerum standum est, ubi certam derogat uetustas fidem; et lacus nomen ab hac recentiore insignitius fabula est". 
rales a los que vuelve cuando muere, entonces los dioses y la religión no tendrían razón de existir ni explicarían cosa alguna. Señala que si se analiza la historia incendios, tempestades y desgracias caen sobre buenos y malos; en las batallas los mejores son los primeros en perecer; en la paz los tiranos como Falaris se imponen y se apoderan de tronos mientras que hombres justos como Rutilio, Camilo y Sócrates fueron exiliados o ejecutados. ${ }^{43}$ Estos hechos podrían poner en tela de juicio la existencia de los dioses o su intervención en los asuntos humanos, lo que se sumaba a la incapacidad de la filosofía por brindar seguridades acerca de lo divino; ello podía confundir y minar la fe en los dioses. A pesar de esto, o mejor dicho gracias a esto, la conclusión que Cecilio extrae de tal cúmulo de incertidumbres y dudas no es la negación de toda religión, sino el apego más fuerte a la religión tradicional que es lo más verosímil y firmemente establecido entre lo ambiguo. Lo más sensato y seguro es aceptar los preceptos de los mayores como custodios de la verdad y adorar a los dioses, no especular sobre ellos, según los antepasados lo fijaron:

Siendo entonces la fortuna cierta o la naturaleza incierta, cuanto más reverente y mejor es acoger la enseñanza de los mayores como sacerdotes de la verdad, observar los ritos religiosos transmitidos; adorar a los dioses, a quienes has sido instruido por nuestros padres a temer antes que conocer a fondo; ni expresar opinión sobre los númenes, sino creer a los antepasados, quienes, aun en una edad ruda, en el nacimiento mismo del mundo, merecieron tener a los dioses propicios o como reyes. ${ }^{44}$

Añade que esto lo hacen todos los pueblos que adoran a sus propios dioses y Roma merece ser la cabeza del mundo por

\footnotetext{
${ }^{43}$ Min. Fel., V.7-12.

${ }^{44}$ Idem, VI.1: "Cum igitur aut fortuna certa aut natura incerta sit quanto venerabilius ac melius antistitem veritatis maiorum excipere disciplinam, religiones traditas colere, deos, quos a parentibus ante inbutus es timere quam nosse familiarius, adorare, nec numinibus ferre sententiam, sed prioribus credere, quid adhuc rudi saeculo in ipsius mundi natalibus meruerunt deos vel faciles habere vel reges".
} 
ejecutarlo escrupulosamente y adoptar a los dioses extranjeros. Los mayores crearon sabiamente las instituciones religiosas y forjaron el ceremonial adecuado; también los magníficos templos de Roma daban fe del lazo con los dioses custodios del Imperio, daban curas a las enfermedades y advertían sobre las desgracias. A la par, recuerda que los logros y derrotas de Roma están ligados a la atención o indiferencia hacia los cultos. De esta manera, se veneraba la religión establecida porque expresaba una antigua tradición que se había mantenido por generaciones; estas características hacían de los cultos ancestrales más creíbles y cercanos a la verdad.

En este punto confluyen tradición y costumbre. Nuevamente, siguiendo los apuntes de Hobsbawm, la costumbre tiene la doble función de ser motor y guía de las sociedades tradicionales. No excluye la innovación y el cambio hasta cierto punto, aunque la petición de compatibilidad o identidad con sus antecedentes le impone límites considerables. Brinda a cualquier cambio, de resistencia o innovación, "la sanción del precedente, la continuidad social y de la ley natural tal como se expresan en la historia". ${ }^{45}$ De este modo, los doctos paganos exaltaron el prestigio y el valor de la tradición como máximo criterio de aceptación religiosa. Prudencio captó el sentir de los nobles como Símaco que veneraban lo viejo y despreciaban lo nuevo en boca del prefecto que juzgaba al mártir Román:

Ahora nos nace el dogma cristiano, después de mil relevos consulares desde que Roma es Roma, por no remontarme a los Néstores. Todo aquello que surgió como nuevo no existió anteriormente $[\ldots]$ ¿Dónde estaba ese dios supremo vuestro cuando Rómulo, niño de Marte, con el favor de los dioses fundaba el bastión de las siete colinas? El poderío de Roma, asentada con buenos augurios, se debe a Júpiter Estator y demás dioses. Esto es lo que ha estado decretado desde siempre, esto es lo que nuestros

\footnotetext{
${ }^{45}$ Hobsbawm, "La invención de la tradición”, en op. cit., pp. 8-9.
} 
ancestros nos han transmitido: hemos de granjearnos el favor de los templos para ayudar a los triunfos del príncipe. ${ }^{46}$

En el mundo clásico se iguala antigüedad con verdad, o cuando menos verosimilitud, así la antigua religión era más digna de fe y próxima a la verdad, pues su autoridad residía en los siglos; mientras más vieja fuera, más cercana estaba a las auténticas fuentes que los dioses utilizaron para comunicarse con los hombres. Roma tenía instituciones religiosas que se remontaban a Rómulo y Numa y que acompañaron su vida espiritual junto con sus triunfos y derrotas. ${ }^{47}$ De este modo, la tradición era la única base segura para sostener el culto de los dioses y la creencia en ellos; las otras vías podían caer en el error y la discusión al depender de autoridades humanas. Símaco resalta este punto al insistir que la identidad religiosa de Roma era palpable en sus ceremonias, templos, ritos y dioses; estos elementos la definían y constituían. La tradición exigía su continuación y aseguraba el apego piadoso a los cultos, "pues cuando todo razonamiento está velado, ¿de dónde proviene un conocimiento más directo sobre los númenes que de la memoria y los testimonios de los sucesos prósperos?"48 La defensa de la religión tradicional había sido un sello de la nobleza romana cada vez que las antiguas tradiciones peligraban, y era un rasgo definitorio de las personas letradas. Al sentirse

${ }^{46}$ Prudent., Perist., X.406-418: "Nunc dogma nobis Christianum nascitur post euolutos mille demum consules ab urbe Roma, ne retexam Nestoras [...] Ubi iste uester tunc erat summus Deus, diuum favore cum puer Mauortius fundaret arcem septicollem Romulus? Quod Roma pollem auspiciato condita, Ioui Statori debet et dis ceteris. Hoc sanctum ab aeuo est, hoc ab atauis traditum: plavanda nobis pro triunfis principis delubra". Las citas latinas de esta obra provienen de la Biblioteca de Autores Cristianos y las españolas de la Biblioteca Clásica Gredos.

${ }^{47}$ Rutilio le decía a Roma personificada "no estamos lejos del cielo por tus templos" (non procul a caelo per tua templa sumus). Rut. Namat., De redit., I.50. Aunque para Tertuliano el Capitolio "es el templo de todos los demonios" (omnium daemonum templum est). Tert., De spect., XII. Las citas latinas de ambas obras provienen de la Loeb Classical Library.

${ }^{48}$ Symmachus, Rel., III.8: "Nam cum ratio omnis in operto sit, unde rectius quam de memoria atque documentis rerum secundarum cognitio venit numinum?" 
custodios de la herencia romana, creían que salvaguardar la tradición romana era lo mismo que defender el antiguo culto; siendo la fe de los mayores parte del legado político y social rechazaban los nuevos cultos por ser supersticiones. ${ }^{49}$ Aunque hubiera nuevos cultos, especialmente los orientales, y los antiguos fueran reinterpretados, el centro de la devoción pagana por el pasado era la religión oficial. Por ello, estas reflexiones y actitudes resaltaron la novedad del cristianismo, lo cual era un fuerte escollo para su pretensión de ser la única vía de salvación y conocimiento de lo divino que quería sustituir a los demás cultos.

La autoridad de la tradición religiosa y la unión de los dioses con Roma hacia que el Estado romano se preocupara por conservar el aparato religioso y los antiguos usos, lo que se ligaba al convencimiento de que este proceder era congruente con la historia romana. En esta línea, Augusto y Tiberio creyeron un deber la restitución de ceremonias, exhibieron aversión a los ritos extranjeros y su preferencia por los romanos en la idea de preservar la unión de Roma con la esfera divina en los mejores términos dentro de la restauración de las antiguas costumbres. ${ }^{50}$ Asimismo, Tácito refiere el interés de Claudio por mantener las instituciones religiosas en todo su esplendor, como el colegio de los arúspices, debido a los servicios prestados a Roma en momentos difíciles al llevar los ritos correctamente. Claudio admitía que se habían desatendido debido a la introducción de cultos extranjeros y que no había problemas en Roma, pero ello no quitaba que debiera "agradecerse los beneficios por la bondad de los dioses para que los ritos y las ceremonias

\footnotetext{
${ }^{49}$ Jaeger, op. cit., p. 103. No extraña entonces que los cristianos se dedicaran a refutar las conclusiones que los paganos extraían de los autores antiguos, pues de ellos extraían su visión del pasado. Arnaldo Momigliano, "Historiografía pagana e historiografía cristiana en el siglo IV D.C.”, en Ensayos de..., pp. 110-111.

${ }^{50}$ Augusto: Suet., Vit. Aug., XXXI, XCIII. Dio Cass., LIII.2.4. Tito Livio lo llama "fundador y restaurador de todos los templos" (templorum omnium conditorem ac restitutorem). Liv., IV.21. Tiberio: Suet., Vit. Tib., XXXVI.
} 
religiosas, celebradas en los tiempos inciertos, no fueran olvidadas en los prósperos". ${ }^{51}$ Procurar la protección de los dioses hacia Roma se volvió más urgente cuando ésta se enfrentaba a diversos problemas internos y externos, haciendo ineludible obtener toda ayuda posible mediante las formas habituales y reclamando a sus habitantes que cerraran filas en torno a él. De esta manera, la adoración de los dioses iba junto con la exigencia de mayor compromiso de los cristianos con el Imperio en tiempo de crisis como el siglo II, pues había cristianos que se negaban a pagar impuestos, a enrolarse en el ejército y a adorar a los dioses protectores del Imperio. Celso expresa este punto cuando invita a los cristianos a abandonar esa postura:

Apoyad al emperador con todas vuestras fuerzas, compartid la defensa del Derecho; combatid por él, si lo exigen las circunstancias; ayudadlo en el control de sus ejércitos [...] tomad vuestra parte en las funciones públicas, si fuere preciso, para la salvación de las leyes y de la causa de la piedad. ${ }^{52}$

No extraña, pues, que la restauración política y militar de los príncipes del siglo III fuera acompañada por varias iniciativas

\footnotetext{
${ }^{51}$ Tac., Ann., XI.15: "sed benignitati deum gratiam referendam, ne ritus sacrorum inter ambigua culti per prospera oblitterarentur". La cita latina proviene de la Scriptorum Classicorum Bibliotheca Oxoniensis. Nota similar en Suet., Vit. Claud., XXII. En el relato de Tácito se menciona el influjo etrusco en la aruspicina, rasgo señalado por varios autores. La presencia etrusca continuó a través del tiempo: arúspices etruscos aparecen en la corte de Diocleciano como instigadores de la persecución según Lactancio, y como acompañantes de Juliano en su campaña persa haciéndole saber que las señales eran adversas en la obra de Amiano. Lact., De Mort. Pers., 10.1-4. Amm. Marc., 23.5.10, 25.2.7-8. Para Sordi, el celo mostrado por Decio y Valeriano en sus persecuciones podría tener una de sus causas en su origen etrusco que era una zona tradicionalista y apegada a los cultos. Marta Sordi, Los cristianos y el Imperio romano, pp. 108-109.

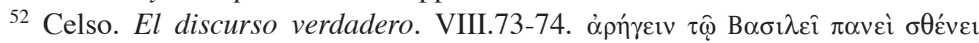

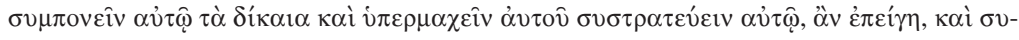

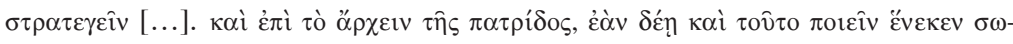

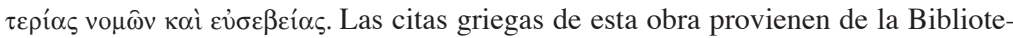
ca Universale Rizzoli y las españolas del Libro del Bolsillo.
} 
de recuperación de los cultos ancestrales. En un mundo donde la religión y la política tenían múltiples puntos de contacto y en que la sacralidad estaba en todas partes, el resguardo de los cultos cumplía una función crucial junto con los deberes civiles y militares. De nuevo Prudencio rescata esa lógica cuando hace decir a un prefecto que debe rendirse el culto a las deidades "a fin de que una campaña propicia secunde su gloria $\mathrm{y}$, subyugando al enemigo, nuestro caudillo refrene con sus leyes un mundo en paz [...] Haber despreciado los templos es haber desdeñado al príncipe". ${ }^{53}$ La excepción eran los judíos, quienes por su monoteísmo excluyente se negaban a adorar a otros dioses. Los romanos les dieron un trato diferente por razones políticas, tolerando su religión a cambio de tributo y la conservación del orden, aunque intervenían cuando era necesario. Asimismo, los judíos poseían una personalidad jurídica y cultural, por lo que, si bien eran despreciados, se reconocía que constituían un pueblo antiguo con sus propias leyes y ritos, a los que eran apegados. Incluso eran alabados por esto, ya que se admitía que todo pueblo debía guardar sus rasgos distintivos para preservar su cohesión interna. ${ }^{54}$

Sin embargo, no se podía permitir que los cristianos desertaran de las costumbres religiosas al quebrantar las leyes de sus patrias y negarse a adorar a los dioses. Si era malo que algunos adoptaran las costumbres judías, era peor con los cristianos, pues no adoraban a los dioses y no constituían un pueblo antiguo. Además, ponían en peligro la pax deorum, ya que, como gran parte de la religión romana era colectiva, se temía que la ira divina cayera sobre Roma por su culpa, hecho que

\footnotetext{
${ }^{53}$ Prudent., Perist., X.418-420, 425: "Faustus ut secundet gloriam procinctus utque subiugatis hostibus doctor quietum frenet orbem legibus [...] spreuisse templa respuisse est principem".

${ }^{54}$ Celso, El discurso verdadero, V.25. Tac., Hist., V.V.1. Para la relación de Roma con los judíos, vid. Juan de Churruca, "La actitud de los judíos de la diáspora en los dos primeros siglos del Principado", en Cristianismo y mundo romano, pp. 39-67.
} 
no debe minimizarse en una época crítica con varias guerras, pestes, desgracias naturales, invasiones, etc. Por ello, los príncipes trataron de atraer a las fuerzas espirituales según los modos usuales que habían probado su eficacia y apelando a nuevas formas como las tendencias sincréticas de los Severos y la preferencia solar de Aureliano. ${ }^{55}$ La tetrarquía de Diocleciano enfatizó la atención de los cultos y se puso a sí misma bajo la égida de los dioses, sobre todo de Júpiter y Hércules, lo cual era continuamente resaltado. Sobre Diocleciano y Maximiano, un panegirista decía:

En efecto, lo primero de todo: ¡cuán grande es vuestra piedad para los dioses! Con altares y estatuas, templos y ofrendas, en fin, con vuestros nombres inscritos y enlazados con sus imágenes adornadas, los hiciste más santos con el ejemplo de vuestra veneración. Sin duda, en verdad, ahora los hombres entienden cuál es el poder de los dioses, cuando son honrados tan vigorosamente por vosotros. ${ }^{56}$

Si bien cada uno podía adorar al dios que quisiese, esto no eximía la adoración de los dioses tradicionales, cuyo cumplimiento estaba a cargo del Estado romano. En medio de las difíciles condiciones por las que atravesaba el Imperio, los tetrarcas requerían todo el apoyo posible de sus gobernados, lo que incluía el culto de las divinidades según las normas habituales. En el edicto de tolerancia de 313, Galerio aclara los motivos de la persecución contra los cristianos: les reprocha su ruptura con las prácticas religiosas tradicionales, que siguieran normas que ellos mismos se habían impuesto, y que ejercieran un feroz

\footnotetext{
${ }^{55}$ SHA. Alex. Sev., 29.2. Aurel., 30.7-10.

${ }^{56}$ Pan. Lat., III.VI.1: "Nam primum omnium quanta uestra est erga deos pietas! Quos aris simulacris, templis donariis, uestris denique nominibus adscriptis, adiunctis imaginibus ornastis sanctioresque fecisti exemplo uenerationis. Nunc enim uere homines intellegunt quae sit potestas deorum, cum tam impense colantur a uobis". La cita latina de esta obra proviene de la Collection des Universités de France.
} 
proselitismo para atraerse a gente de todo tipo y lugar, lo cual resulta un desvarío. También señala que el gobierno imperial buscaba imitar la conducta respetuosa de los mayores hacía lo antiguo según lo probaba la historia romana, y reiteraba el deber del Estado de conservar las cosas recibidas desde tiempos remotos y castigar a quienes se opongan a la costumbre, todo esto buscando el bienestar de Roma. ${ }^{57}$

La alianza de los dioses con Roma, el deseo de conservar su buena voluntad, la antigüedad como criterio superior de aceptación de una religión y la punición a quienes introducen innovaciones en los usos tradicionales son temas que continuamente surgen en estos textos que evidencian la necesidad de unidad en situaciones críticas que amenazaban la estabilidad del Imperio. En medio de los conflictos que enfrentaban a los distintos emperadores y aspirantes tras la disolución de la tetrarquía, Maximino señala en un edicto que el servicio a los dioses se debía a su gratitud por la buena cosecha y el buen tiempo que aquéllos brindaban porque se les rendía el culto adecuado. Con esto justificaba plenamente el castigo de quienes se negaban a adorarlos y ponían en peligro su favor. ${ }^{58}$ Venerar a los dioses según los modos que habían sido eficaces y que habían acompañado a Roma desde su origen, significaba continuar con el rasgo propio que marcaba la historia romana y que caracterizaba a los romanos: la continuidad y el respeto a las costumbres, especialmente las religiosas. La liga con las deidades que aseguraban su protección a Roma era un deber del Estado que podía emplear todos los medios disponibles

\footnotetext{
${ }^{57}$ Lact., De Mort. Pers., 34.1-2. Para la relación de los emperadores con los cultos y los motivos y fases de la persecución: Mary Beard, John North y Simon Price, Religions of Rome, v. 1, pp. 239-244. G. E. M. de Ste. Croix, “Por qué fueron perseguidos los primeros cristianos?", en Finley, op. cit., pp. 262-269. Sordi, op. cit., pp. 12-14.

${ }^{58}$ Euseb., Hist. Eccl., IX.5-7. Aunque había quienes dudaban de los cultos y tenían una visión filosófica de los dioses, no se negaban a sacrificar, lo que sí hacían los cristianos. Churruca, "El proceso de Dionisio de Alejandría", en op. cit., pp. 512-514. Ste. Croix, “¿Por qué...?”, en Finley, op. cit., p. 265.
} 
para ello en un mundo en que religión y política se unían estrechamente y se validaban mutuamente. A la par, el respeto a la tradición estaba ligado a la sujeción a la autoridad y el gobierno podía exigir ambas, y no dudaba en hacerlo, como una sola cosa. Celso lo notó y dijo que debía seguirse los hábitos "no sólo porque los diferentes pueblos se dotaron de diferentes leyes y que es preciso que en cada Estado los ciudadanos sigan las leyes establecidas [...] Así habría impiedad en infringir las leyes establecidas desde el origen". ${ }^{59}$ Cabe aclarar que esa actitud no solamente fue ejercida contra los cristianos, sino también hacia los maniqueos que representaban una amenaza similar. Esto es claro en un edicto de Diocleciano contra ellos y que responde a la misma lógica. En él se señala que no se pueden aceptar doctrinas persas porque son torpes, vanas y se oponen a lo establecido por los dioses desde antiguo:

Pero los dioses inmortales por su providencia se dignaron a ordenar y disponer que las cosas que son buenas y verdaderas fueran aprobadas y establecidas en su integridad, por el consejo y deliberación de muchos varones no sólo buenos sino también ilustres y sapientísimos, a quienes no está permitido ni enfrentarlos ni resistirlos, y una vieja religión no debiera ser criticada por una nueva. Sin duda, es propio del más grande crimen volver a tratar las cosas que una vez establecidas y definidas por los antiguos tienen y poseen su estado y curso. ${ }^{60}$

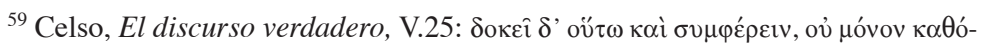

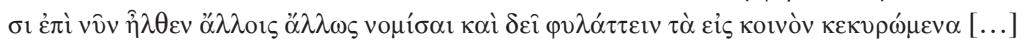

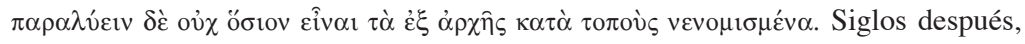
Agustín dirá algo similar al escribir que debía evitarse la violación de las costumbres humanas según cada pueblo con el fin de mantener la armonía interna, ya que era indecorosa la parte que no se amoldaba al todo. August., Conf., III.8.15.

${ }^{60}$ Comp. leg. mos. et Rom., 15.3.2: "sed dii inmortales prouidentia sua ordinare et disponere dignati sunt, quae bona et uera sunt ut multorum et bonorum et egregorium uirorum et sapientissimorum consilio et tractatu inbilata probarentur et statuerentur, quipus nec obuiam ire nec resistere fas est, neque reprehendi a noua uetus religio deberet. maximi enim criminis est retractare quae semel ab antiquis statuta et definita suum statum et cursum tenent ac possident". La cita latina y la española provienen de la Bibliotheca Iuridica Latina Mexicana.
} 
Más adelante continua diciendo que los maniqueos son merecedores de castigo por oponer nuevas supersticiones a los viejos cultos y por excluir las cosas concedidas por voluntad divina desde tiempos ancestrales, favoreciendo novedades que conducían al error. ${ }^{61}$ Así, los emperadores se creían los restauradores del valor romano en los campos de batalla y los émulos de los grandes romanos del pasado. Al igual, consideraban que la autoridad de los mayores no debía ser socavada, sino preservarse como las restantes costumbres romanas. Como los orgullosos herederos de las virtudes romanas, vieron al cristianismo como la gran amenaza a los hábitos de los antepasados que eran las bases del Estado romano. Por ello no extraña que Juliano dijera sobre su actitud hacia la tradición: "soy precavido como nadie y huyo de la novedad en todo, por decirlo así, y en lo particular en lo referente a los dioses, creyendo que es necesario guardar desde el principio las leyes tradicionales". ${ }^{62}$

La continuación de las costumbres era un rasgo notable que los romanos vieron en su propia historia. La sociedad romana tenía una vena profundamente tradicionalista y educada en el respeto y recuerdo del pasado, así como en la emulación de las gestas de los ancestros. Debido a esto, eran bastante reacios a los cambios radicales, aunque no estaban totalmente cerrados a tal posibilidad. Este hecho también influyó en sus hábitos religiosos que se percibían como constitutivos del pueblo romano y como un elemento valioso que lo definía.

\footnotetext{
${ }^{61}$ Idem, 15.3.3-4.

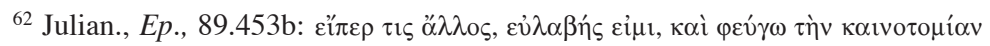

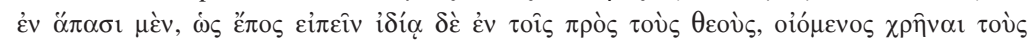

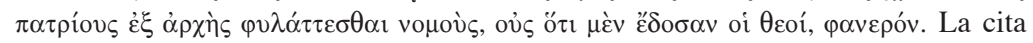
griega proviene de la Collection des Universités de France y al española de la Biblioteca Clásica Gredos. No sorprende su actitud ante otros, pues "maltrató la memoria de Constantino como renovador y agitador de las leyes antiguas y de las costumbres antiguamente recibidas" ("Tunc et memoriam Constantini, ut novatoris turbatorisque priscorum legum et mores antiquitus recepti, vexavit”). Amm. Marc., 21.10.8.
} 
Los romanos eran muy abiertos a la adopción de dioses extranjeros, lo que se veía como un acierto y una manera de atraerse y hacer propicias a todas las fuerzas espirituales. Al ser parte integrante de la identidad romana y de la alianza con los dioses, los cultos debían ser preservados y no podía permitirse su abandono, principalmente en tiempos delicados. Esto explica que el intento de Heliogábalo de abolir los cultos en Roma y en el mundo para que su dios fuera adorado por todos, llegando a afirmar que los otros dioses eran sirvientes del suyo, fuera visto como una locura. El saqueo de estatuas y objetos sagrados de los templos para trasladarlos al de su dios, al igual que su propio matrimonio con una vestal que simbolizaba la unión de su deidad con una diosa romana son percibidos como aberraciones. ${ }^{63}$ En el ideario que Dión Casio pone en boca de Mecenas, en oposición con las tendencias sincréticas de los Severos, se insiste en seguir los cultos tradicionales según los usos patrios y castigar a quienes contaminen los ritos religiosos. Asimismo, se condena la sustitución de los dioses tradicionales por deidades extranjeras y nuevas que incitan conjuras y sediciones que alteran el orden público; por otro lado, alienta la adivinación por parte de los magistrados religiosos, pero reprueba la de los particulares. ${ }^{64}$

La filiación de los cultos religiosos con Roma y la insistencia en la persistencia de la tradición como característica de la historia romana se acentuó a partir de que el cristianismo adquirió una posición dominante y se volvió más agresivo hacia otras religiones. Mientras que en Oriente hubo un ambiente propicio que llevó a la adopción del cristianismo por las capas

\footnotetext{
${ }^{63}$ SHA. Heliogab., 6.7-9, 7.1-6. Empero, el culto solar llegó a ser muy importante en los años venideros y tuvo implicaciones filosóficas. Un panorama en John Ferguson, Le religioni nell'impero romano, pp. 45-47. Beard, North y Price, op. cit., v. 1, pp. 243-244. Cumont, op. cit., pp. 110-118.

${ }^{64}$ Dio Cass., LII.36.1-4. Para el ambiente sincrético de la etapa severa que no satisfacía a paganos ni a cristianos, vid. Sordi, op. cit., pp. 88-91. E. R. Dodds, $P a$ ganos y cristianos en una época de angustia. Algunos aspectos de la experiencia religiosa desde Marco Aurelio a Constantino, pp. 149-151.
} 
urbanas que entraban al gobierno imperial que favorecía a los cristianos, la nobleza senatorial de Occidente instruida en la obediencia a la tradición fue una tenaz defensora de los viejos cultos, pues eran el centro de la devoción romana por la costumbre. ${ }^{65} \mathrm{El}$ sentido de grupo, la historia y la literatura con su mirada nostálgica del pasado glorioso y pagano de Roma confluyeron en que la aristocracia romana permaneciera fiel a la antigua religión hasta finales del siglo IV. Por ello Símaco insistía en que no se podía ir en contra de las costumbres de los mayores, en las que los cultos religiosos ocupaban un papel fundamental, sino lo piadoso era salvaguardar los hábitos legados. Según Símaco, la historia enseñaba que los romanos eran fieles en cuidar su legado, mientras que el cambio era un elemento desestabilizador que creaba conflictos en la sociedad. Todo hombre sensato era quien se preocupara por custodiar las cosas como las había recibido y sin introducir modificaciones, lo que estaba en armonía con el espíritu y tradición de Roma. Ante la falta de apoyo oficial de los emperadores cristianos a los cultos, recordaba que la historia decía que los romanos eran prestos en proteger su legado. Dirigiéndose a los emperadores, exclamaba: "Aseguren, les ruego, que lo que recibimos de niños, de viejos lo dejemos a la posteridad. El amor a la costumbre es grande", para después insistir en que "si un largo tiempo brinda autoridad a los cultos, debe mantenerse una fe de tantos siglos y seguir a nuestros padres, quienes felizmente siguieron a los suyos". ${ }^{66}$ También Zósimo recogió el sentimiento de este grupo al relatar la postura de

\footnotetext{
${ }^{65}$ Sobre estos temas son clásicos los trabajos de A. H. M. Jones, "El trasfondo social de la lucha entre cristianismo y paganismo", y Herbert Bloch, "El renacimiento del paganismo en Occidente a fines del siglo IV", en Momigliano, El conflicto..., pp. 34-51, 207-231.

${ }^{66}$ Symmachus. Rel., III.4.8: "Praestate, oro vos, ut ea quae pueri suscepimus, senes posteris relinquamus. Consuetudinis amor magnus est [...] Iam si longa aetas auctoritatem religionibus faciat, servanda est tot saeculis fides et sequendi sunt nobis parentes, qui secuti sunt feliciter suos".
} 
buena parte de los aristócratas cuando Teodosio llegó a Roma tras su victoria sobre Eugenio y los conminó a aceptar el cristianismo.

Puesto que el Senado perseveraba en las tradiciones patrias de antaño y mantenía aún el parecer de no dejarse llevar junto a quienes se habían inclinado al desprecio de los dioses, lo convocó para exponer ante él un discurso en el que los exhortaba a abandonar el extravío (según él lo llamaba) al que hasta entonces se dieron y a elegir la fe de los cristianos, que prometía absolver de todo error e impiedad. Ninguno quedó convencido por su exhortación, ni quiso nadie apartarse de las ancestrales tradiciones que databan cuando la ciudad fue fundada para anteponer a ella un acatamiento absurdo. ${ }^{67}$

La fidelidad al hábito heredado fue un elemento distintivo de los aristócratas instruidos y educados en la observancia de la tradición. Los nobles romanos vieron en el culto religioso un signo crucial del lazo con la cultura y el pasado glorioso de Roma que la había hecho grande y que los definía como grupo y pueblo. Como custodios de ese legado, consideraban su deber resguardar la buena relación de los dioses con Roma y, ligado a esto, consolidar la obediencia a la autoridad constituida en un tiempo en que las mores maiorum englobaban el cultivo de los cultos y el sometimiento a las normas del Estado romano. Como la costumbre no admitía discusión, era sedicioso e impío que lo antiguo fuera socavado por lo nuevo y no aprobado por el valor que los años daban. Ante esto, Zósimo remarca que la abolición de los sacrificios y ceremonias

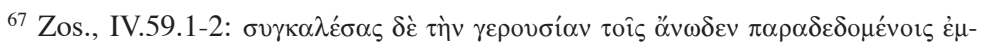

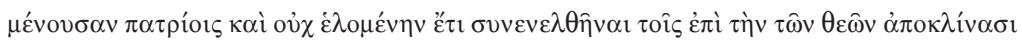

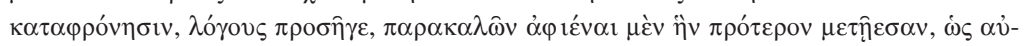

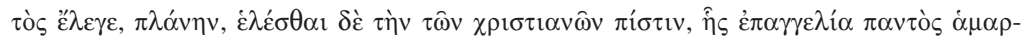

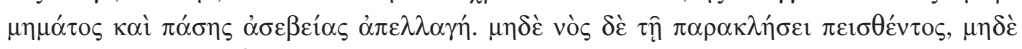

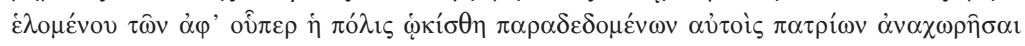

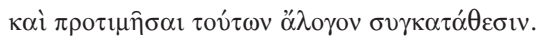


por la situación del erario que Teodosio alegaba, tuvo funestas secuelas para Roma, pues "cesaron entonces los ritos sacrificiales y, asimismo quedaron descuidados cuantas otras cosas concernían a las tradiciones patrias, con lo que el Imperio Romano, progresivamente disminuido, llegó a convertirse en morada de bárbaros". ${ }^{68}$

A pesar de la consolidación del cristianismo en la sociedad romana, esto no evitó que se conservaran ciertas actitudes tradicionales en varias esferas. Por ejemplo, la creencia de que el bienestar de Roma dependía del culto a los dioses tuvo su contrapartida cristiana en la relación entre el plan divino y el poder romano; en esta dinámica Roma obtuvo su dominio gracias al único Dios. Así como negarse a adorar a los dioses era considerado traición e impiedad que justificaban la persecución de cristianos, ahora el paganismo y la herejía eran delitos contra Dios y el Estado, por lo que éste podía dictar leyes en contra de paganos y herejes. ${ }^{69}$ En esta línea, Agustín presentaba a la Iglesia como la verdadera y la que reunía a la mayoría, por lo que podía aplicar a sus rivales las mismas penas que había sufrido en otro tiempo. Además, proclamaba la autoridad de la Iglesia y la tradición como elementos fundamentales para definir la exégesis correcta del Evangelio; así, la autoridad establecida en materia religiosa se convertía en factor sustancial para delimitar lo correcto e incorrecto, y no permitía desafíos ni dudas. Por otro lado, la activa participación de algunos cristianos de Roma en la Lupercales a principios del siglo vi provocó la indignación de su obispo; esos cristianos justificaron su actuación al señalar que las fiestas

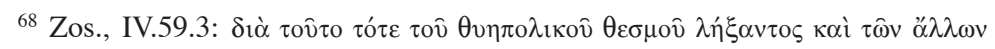

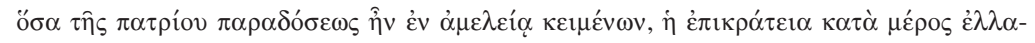

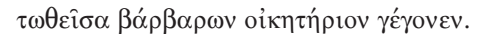

${ }^{69}$ José Fernández Ubiña, "Espiritualidad pagana y cristiana en el mundo mediterráneo en el Bajo Imperio”, en Minerva Alganza Roldán y Francisco A. Muñoz (eds.), Confluencia de culturas en el Mediterráneo, pp. 65-73. Sordi, op. cit., pp. 138-139.
} 
tradicionales eran forzosas para la prosperidad de Roma. ${ }^{70} \mathrm{La}$ sociedad romana tenía una línea tradicionalista que reiteradamente tomaba al pasado como un espejo en el que podía verse para criticar o alabar actitudes dependiendo del contexto histórico. El recuerdo de los mayores, la historia, las costumbres, los edificios, etcétera, servían de enlace con las tradiciones de un pasado digno que funcionaba como dador de ejemplos y pautas de conducta para modelar el presente. Múltiples factores recordaban la gran unión entre las edades y estimulaban la observancia irrestricta a lo heredado por los antepasados como digno de imitarse. La religión fue uno de los campos más importantes de esta continuidad, por lo que debía salvaguardarse a pesar de las objeciones y con mayor razón en etapas de crisis. Aunque el cristianismo se impuso, el respeto al legado antiguo se manifestó de varias formas, algunas menos visibles que otras, pero atestiguan la persistencia y el arraigo en distintos fenómenos y episodios históricos.

\footnotetext{
${ }^{70}$ Beard, North y Price, op. cit., v. 2, p. 163. Brown, El primer milenio..., p. 54. En una óptica parecida está la interpretación que Liebeschuetz hace sobre los Saturnalia de Macrobio como una obra que insistía en que las formas usuales de pensamiento y conducta habían hecho y conservado grande a Roma. Como la religión era parte crucial de la tradición, también debía ser estudiada, y concluía que los dioses eran personificaciones de aspectos del sol desde la perspectiva del ritual y la iconografía. Siendo los dioses la parte más objetable de los cultos, esto vendría a señalar que la religión tradicional tenía bases monoteístas y que la incompatibilidad con la nueva religión no era total; lo que haría más fácil a los nobles contemporáneos de Macrobio reconciliar su cristianismo recién adoptado con la continua veneración del pasado. J. H. W. G. Liebeschuetz, Decline and Fall of the Roman City, pp. 324-327.
} 


\section{BIBLIOGRAFÍA}

\section{Fuentes antiguas}

Agustín, Las Confesiones, trad., introd. y notas de Olegario García de la Fuente, Madrid, Akal (Akal Clásica, 1), 1986.

Ammianus Marcellinus II, trad. y notas de John C. Rolfe, Londres y Cambridge, William Heinemann Ltd-Harvard University Press (The Loeb Classical Library), 1950.

ApUlEYo, El asno de oro, trad., introd. y notas de Francisco Pejenaute Rubio, Madrid, Akal (Akal Clásica, 11), 1988.

Aurelio Prudencio, Obras Completas, trad. e introd. de José Guillén, Madrid, Editorial Católica (Biblioteca de Autores Cristianos, 58), 1963.

Aurelius Augustinus, De civitate Dei I, ed. crítica de Bernardus Dombart y Alfonsus Kalb, Stuttgart, Teubner (Bibliotheca Scriptorum Graecorum et Romanorum Teubneriana), 1981.

Celso, Contro i Cristiani, introd. de Gianni Baget Bozzo, trad. y notas de Salvatore Rizzo, Milán, Rizzoli (BUR Classici Greci e Latini), 2002 (4a. reimp.).

-, El discurso verdadero contra los cristianos, trad. e introd. de Serafín Bodelón, Madrid, Alianza Editorial (El libro del bolsillo, 1324), 1988.

Cicero, Orationes, ed. crítica de Guglielmus Peterson, Oxford, Oxford University Press (Scriptorum Classicorum Bibliotheca Oxoniensis), 1978 (9a. reimp.).

CiCERón, De la adivinación, trad., introd. y notas de Julio Pimentel Álvarez, México, UNAM-Instituto de Investigaciones Filológicas (Bibliotheca Scriptorum Graecorum et Romanorum Mexicana), 1988.

-, De la república, trad., introd. y notas de Julio Pimentel Álvarez, México, UNAM-Instituto de Investigaciones Filológicas (Bibliotheca Scriptorum Graecorum et Romanorum Mexicana), 1984.

-, Sobre la naturaleza de los dioses, trad., introd. y notas de Julio Pimentel Álvarez, UNAM-Instituto de Investigaciones Filológicas (Bibliotheca Scriptorum Graecorum et Romanorum Mexicana), 1976.

Clemente de Alejandría, Protréptico, trad., introd. y notas de María Consolación Iriart Hernández, Madrid, Gredos (Biblioteca Clásica Gredos, 199), 1994.

Comparación de leyes mosaicas y romanas, trad., introd. y notas de Martha Elena Montemayor Aceves, México, UNAM-Instituto de Investigaciones Filológicas-Instituto de Investigaciones Jurídicas (Bibliotheca Iuridica Latina Mexicana, 5), 1994. 
Der Streit um den Victoriaaltar, Die 3, Relatio des Symmachus und die Briefe 17, 18 und 57 des Ambrosius, ed. de Richard Klein, Darmstadt, 1972.

Dio, Roman History VI, trad. de Ernest Cary, Londres y Cambridge, Harvard University Press-William Heinemann (The Loeb Classical Library), 1955.

Dionisio De Halicarnaso, Historia antigua de Roma I-III, introd. de Domingo Plácido, trad. y notas de Elvira Jiménez y Ester Sánchez, Madrid, Gredos (Biblioteca Clásica Gredos, 73), 1984.

Dionysius of Halicarnassus, Roman Antiquities I, trad. introd y notas de Earnest Cary, Londres y Cambridge, William Heinemann Ltd-Harvard University Press (The Loeb Classical Library, 319), 1948 (1a. reimp.).

Eusebio de Cesarea, Historia Eclesiástica, trad. de Luis M. de Cádiz, introd. de Luis Aznar, Buenos Aires, Editorial Nova, 1950.

Historia Augusta, trad., introd. y notas de Vicente Picón y Antonio Cascón, Madrid, Akal (Akal Clásica, 16), 1989.

Juliano, Discursos VI-XII, trad., introd. y notas de José García Blanco, Madrid, Gredos (Biblioteca Clásica Gredos, 17), 1979.

-, Contra los galileos-Cartas y fragmentos-Testimonios-Leyes, trad., introd. y notas de José García Blanco, Madrid, Gredos (Biblioteca Clásica Gredos, 47), 1982.

Jullien, Lettres et Fragments I, texte établi et traduit par Joseph Bidez, París, Société d'Édition "Les Belles Lettres" (Collection des Universités de France), 2005 (5a. reimp.).

Juvenal, Sátiras, trad., introd. y notas de Roberto Heredia Correa, México, UNAM-Instituto de Investigaciones Filológicas (Bibliotheca Scriptorum Graecorum et Romanorum Mexicana, 1974).

LaCtancio, Instituciones Divinas IV-VII, trad. y notas de Eustaquio Sánchez y Salor, Madrid, Gredos (Biblioteca Clásica Gredos, 137), 1990.

- Sobre la muerte de los perseguidores, trad., introd. y notas de Ramón Teja, Madrid, Gredos (Biblioteca Clásica Gredos, 46), 1982.

Libanio, Discursos. Autobiografía, trad., introd. y notas de Antonio Melero Bellido, Madrid, Gredos (Biblioteca Clásica Gredos, 290), 2001.

Luciano, Obras I, introd. de José Alsina Cota, trad. y notas de Andrés Espinosa Alarcón, Madrid, Gredos (Biblioteca Clásica Gredos, 42), 1981.

- Obras II, trad. y notas de José Luis Navarro González, Madrid, Gredos (Biblioteca Clásica Gredos, 113), 1988.

Marco Aurelio, Meditaciones, trad y notas de Ramón Bach Pellicer, introd. de Carlos García Gual, Madrid, Gredos (Biblioteca Clásica Gredos, 5), 1977. 
Panégyriques Latins I, texte établi et traduit par Édouard Galletier, París, Société d'Édition "Les Belles Lettres" (Collection des Universités de France), 1949.

PERSIO, Sátiras, trad., introd. y notas de Germán Viveros, México, UNAMInstituto de Investigaciones Filológicas (Bibliotheca Scriptorum Graecorum et Romanorum Mexicana), 1987.

Petronio, Satiricón, trad., introd. y notas de Roberto Heredia Correa, México, UNAM-Coordinación de Humanidades (Bibliotheca Scriptorum Gracorum et Romanorum Mexicana), 1997.

Plutarchus, Vitae Parellelae I, ed. crítica de Konrat Ziegler, Leipzig, BSB B. G. Teubner Verlagsgesellschaft (Bibliotheca Scriptorum Graecorum et Romanorum Teubneriana), 1969.

PlutARCo, Vidas Paralelas II, trad., introd. y notas de Aurelio Pérez Jiménez, Madrid, Gredos (Biblioteca Clásica Gredos, 215), 1996.

PoliBIO, Historias V-XV, trad. y notas de Manuel Balasch Recort, Madrid, Gredos (Biblioteca Clásica Gredos, 43), 1981.

Polybe, Histories VI, texte établi et traduit par Raymond Weil y Claude Nicolet, París, Société d'Édition "Les Belles Lettres" (Collection des Universités de France), 1977.

Porfirio, Sobre la abstinencia, trad., introd. y notas de Miguel Periago Lorente, Madrid, Gredos (Biblioteca Clásica Gredos, 69), 1984.

Porphyrius, Opuscula selecta, ed. crítica de Augustus Nauck, Stuttgart, B G Teubner (Bibliotheca Scriptorum Graecorum et Romanorum Teubneriana), 1977.

Prudencio, Obras II, trad. y notas de Luis Rivero García, Madrid, Gredos (Biblioteca Clásica Gredos, 241), 1997.

Rutilius Namatianus, De reditu suo, en Minor Latin Poets, trad. e introd. de J. Wight Duff y Arnold M. Duff (3a. ed.), Londres y Cambridge, William Heinemann Ltd-Harvard University Press (The Loeb Classical Library), 1961.

Suetonio, Vidas de los Doce Césares, introd. de Antonio Ramírez de Verger, trad. de Rosa María Aguado Cubas, Madrid, Gredos (Biblioteca Clásica Gredos, 167 y 168), 1992, 2 vols.

TÁcito, Historias III-V, trad. y notas de José Tapia Zúñiga, México, UNAM-Coordinación de Humanidades (Bibliotheca Scriptorum Graecorum et Romanorum Mexicana), 1999.

TAcitus, Annalium ab excessu divi Augusti libri, ed. crítica de C. D. Fischer, Oxford, Oxford University Press (Scriptorum Classicorum Bibliotheca Oxoniensis), 1981.

Tertuliano, Apologético-A los gentiles, trad. introd. y notas de Carmen Castillo García, Madrid, Gredos (Biblioteca Clásica Gredos, 285), 2001. 
Tertullian, Apología-De spectaculis, Minucius Felix, Octavius, trad. de Gerald H. Rendall, Londres y Cambridge, Harvard University PressWilliam Heinemann (The Loeb Classical Library), 1966 (4a. reimp.).

The Scriptores Historiae Augustae, trad. introd. y notas de David Magie, 3a. reimp., Londres y Cambridge, Harvard University Press-William Heinemann Ltd (The Loeb Classical Library, 263), 1968.

Titus Livius, Ab urbe condita I-V, ed. crítica de Robertus Maxwell Ogilvie, Oxford, Oxford University Press (Scriptorum Classicorum Bibliotheca Oxoniensis), 1974.

-, Ab urbe condita VI-X, ed. crítica de Carolus Flamstead Walters y Robertus Seymour Conway, Oxford, Oxford University Press (Scriptorum Classicorum Bibliotheca Oxoniensis), 1988.

Zosime, Histoire Nouvelle II, texte établi et traduit par François Paschoud, París, Société d'Édition "Les Belles Lettres" (Collection des Universités de France), 1979.

Zósimo, Nueva Historia, trad., introd. y notas de José María Candau Marón, Madrid, Gredos (Biblioteca Clásica Gredos, 179), 1992.

\section{Fuentes modernas}

AlföLdy, Géza, Historia social de Roma, trad. de Víctor Alonso Troncoso, Madrid, Alianza Editorial (Alianza Universidad, 482), 1984.

BARB, A. A., "La supervivencia de las artes mágicas", en Arnaldo Momigliano (ed.), El conflicto entre el paganismo y el cristianismo en el siglo IV, trad. de Marta Hernández Iñiguez, pref. de Javier Arce, Madrid, Alianza Editorial (Alianza Universidad, 614), 1989, pp. 117143.

BAYET, Jean, La religion romana, trad. de Miguel Ángel Elvira, Madrid, Cristiandad (Biblioteca de Historia de las Religiones), 1984.

BeArd, Mary, John North y Simon Price, Religions of Rome, Cambridge, Cambridge University Press, 2000 (3a. reimp.), 2 vols.

BLOCH, Herbert, "El renacimiento del paganismo en Occidente a fines del siglo IV", en Momigliano (ed.), El conflicto entre el paganismo y el cristianismo en el siglo IV, trad. de Marta Hernández Iñiguez, pref. de Javier Arce, Madrid, Alianza Editorial (Alianza Universidad, 614), 1989, pp. 207-231.

Brown, Peter, El primer milenio de la cristiandad occidental, trad. de Teófilo de Lozoya, Barcelona, Crítica (La construcción de Europa), 1997.

-, The world of Late Antiquity. From Marcus Aurelius to Muhammad, Londres, Thames and Hudson, 1971. 
Brunt, P. A., "La plebe romana", en Moses Finley (ed.), Estudios de Historia Antigua, trad. de Ramón López, Madrid, Akal (Akal Universitaria, 8), 1981, pp. 87-117.

CAmeron, Averil, El mundo mediterráneo en la Antigüedad tardía (395600), trad. de Teófilo de Lozoya, Barcelona, Crítica (Crítica Arqueología), 1998.

Churruca, Juan de, "La actitud de los judíos de la diáspora en los dos primeros siglos del Principado", en Cristianismo y mundo romano, Bilbao, Universidad de Deusto, 1988, pp. 39-67.

-, "El proceso de Dionisio de Alejandría", en Cristianismo y mundo romano, Bilbao, Universidad de Deusto, 1988, pp. 487-519.

Cochrane, Charles Norris, Cristianismo y cultura clásica, trad. de José Carner, México, Fondo de Cultura Económica (Sección de obras de Historia), 1992 (2a. reimp.).

Cumont, Franz, Las religiones orientales y el paganismo romano, trad. de José Carlos Bermejo Barrera, Madrid, Akal (Akal Universitaria, 105), 1987.

DodDs, E. R, Paganos y cristianos en una época de angustia. Algunos aspectos de la experiencia religiosa desde Marco Aurelio a Constantino, trad. de J. Valiente Malla, Madrid, Cristiandad (El libro del bolsillo Cristiandad, 25), 1975.

DuMÉzIL, Georges, La religion romaine archaïque, París, Payot (Les religions de l'humanité), 1966.

FERGUSON, John, Le religioni nell'impero romano, trad. de Cecilia Gatto Trocchi, Roma-Bari, Laterza (Biblioteca di Cultura Moderna, 758), 1974.

FERnÁNDEZ UBIÑA, José, "Espiritualidad pagana y cristiana en el mundo mediterráneo en el Bajo Imperio", en Minerva Alganza Roldán y Francisco A. Muñoz (eds.), Confluencia de culturas en el Mediterráneo, Granada, Universidad de Granada (Eirene, 2), 1993, pp. 57-78.

FrankfurTer, David, "Traditional Cult", en David S. Potter (ed.), A Companion to the Roman Empire, Oxford, Blackwell, 2006, pp. 543-564.

HoBSBAwM, Eric, "La invención de la tradición", en Eric Hobsbawm y Terence Pranger (eds.), La invención de la tradición, trad. de Omar Rodríguez, Barcelona, Crítica (Libros de Historia), 2002, pp. 7-22.

Hopkins, Keith, Conquistadores y esclavos, trad. de Marco Aurelio Gilmorini, Barcelona, Editorial Península (Historia, Ciencia, Sociedad, 169), 1981.

JAEGER, Werner, Cristianismo primitivo y paideia griega, trad. de Elsa Cecilia Frost, México, Fondo de Cultura Económica (Breviarios, 182), 2001 (8a. reimp.). 
Jones, A. H. M., "El trasfondo social de la lucha entre cristianismo y paganismo", en Momigliano (ed.), El conflicto entre el paganismo y el cristianismo en el siglo IV, trad. de Marta Hernández Iñiguez, pref. de Javier Arce, Madrid, Alianza Editorial (Alianza Universidad, 614), 1989, pp. 34-51.

Liebeschuetz, J. H. W. G., Continuity and Change in Roman religion, Oxford, Oxford University Press, 1979.

-, Decline and Fall of the Roman City, Londres, Oxford University Press, 2001.

MazzARino, Santo, Storia sociale del vescovo Ambrogio, Roma, L'Erma di Bretscheneider (Problemi e ricerche di storia antica, 4), 1989.

Momigliano, Arnaldo, "Historiografía pagana e historiografía cristiana en el siglo IV D. C.", en Ensayos de historiografía antigua y moderna, trad. de Stella Mastrangelo, México, Fondo de Cultura Económica (Sección de obras de Historia), 1997 (1a. reimp.), pp. 95-111.

-, "Las creencias religiosas populares y los historiadores", en Ensayos de historiografía antigua y moderna, trad. de Stella Mastrangelo, México, Fondo de Cultura Económica (Sección de obras de Historia), 1997 (1a. reimp.), pp. 124-139.

- (ed.), El conflicto entre el paganismo y el cristianismo en el siglo $I V$, trad. de Marta Hernández Iñiguez, pref. de Javier Arce, Madrid, Alianza Editorial (Alianza Universidad, 614), 1989.

Pina Polo, Francisco, Marco Tulio Cicerón, Barcelona, Ariel, 2005.

Ramos JuRADO, E. A., "Mito y religión en la filosofía griega a fines del mundo antiguo", en José Luis Calvo Martínez (ed.), Religión, Magia y Mitología en la Antigüedad clásica, Granada, Universidad de Granada (Biblioteca de Estudios Clásicos, 8), 1998, pp. 221-237.

Rives, James, "Religion in the Roman empire", en Janet Huskinson (ed.), Experiencing Rome. Culture, Identity and Power in the Roman Empire, Londres, Routledge-The Open University, 2000, pp. 245-275.

SAlLes, Catherine, Los bajos fondos de la Antigüedad, trad. de César Ayra, Buenos Aires, Juan Granica Ediciones (Las historias de la historia), 1983, pp. 240-242.

SCHEID, John, "El sacerdote", en Andrea Giardina (ed.), El hombre romano, trad. de Jimena Castillo Vejarano, Madrid, Alianza Editorial, 1991, pp. 69-101.

SoRDI, Marta, Los cristianos y el Imperio romano, trad. de Amanda Rodríguez Fierro, Madrid, Ediciones Encuentro (Ensayos, 49), 1988.

Ste. Croix, G. E. M. de, La lucha de clases en el mundo griego antiguo, trad. de Teófilo de Lozoya, Barcelona, Crítica (Crítica Arqueología), 1988. 
Ste. Croix, G. E. M. de, “¿Por qué fueron perseguidos los primeros cristianos?”, en Moses Finley (ed.), Estudios de Historia Antigua, trad. de Ramón López, Madrid, Akal (Akal Universitaria, 8), 1981, pp. 233273.

VERnANT, Jean-Pierre, Entre mito y política, trad. de Hugo Francisco Bauzá, México, Fondo de Cultura Económica (Sección de obras de Historia), 2002.

VeYnE, Paul, "El Imperio romano", en Phillipe Ariès y Georges Duby (eds.), Historia de la vida privada, trad. de Francisco Pérez Gutiérrez y Javier Arce, Madrid, Taurus, 1989 (6a. reimp.), 5 vols. vol. 1. pp. 9-227. 